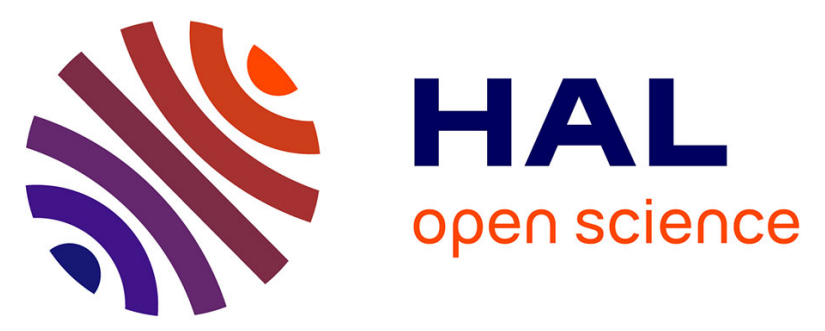

\title{
Assessment of the impacts of climate variability on total water storage across Africa: implications for groundwater resources management
}

Tales Carvalho Resende, Laurent Longuevergne, Jason Gurdak, Marc Leblanc, Guillaume Favreau, Nienke Ansems, Jac van Der Gun, Cheikh Gaye, Alice Aureli

\section{To cite this version:}

Tales Carvalho Resende, Laurent Longuevergne, Jason Gurdak, Marc Leblanc, Guillaume Favreau, et al.. Assessment of the impacts of climate variability on total water storage across Africa: implications for groundwater resources management. Hydrogeology Journal, 2019, 27 (1), pp.493-512. 10.1007/s10040-018-1864-5 . insu-01891409

\section{HAL Id: insu-01891409 \\ https://hal-insu.archives-ouvertes.fr/insu-01891409}

Submitted on 9 Nov 2018

HAL is a multi-disciplinary open access archive for the deposit and dissemination of scientific research documents, whether they are published or not. The documents may come from teaching and research institutions in France or abroad, or from public or private research centers.
L'archive ouverte pluridisciplinaire HAL, est destinée au dépôt et à la diffusion de documents scientifiques de niveau recherche, publiés ou non, émanant des établissements d'enseignement et de recherche français ou étrangers, des laboratoires publics ou privés. 
1 Assessment of the impacts of climate variability on total water storage across

2 Africa: implications for groundwater resources management

3 Tales Carvalho Resende, UNESCO International Hydrological Programme (IHP), Paris, France ${ }^{1}$

4 Laurent Longuevergne, University of Rennes, Géosciences Rennes - UMR 6118, Rennes, France

5 Jason J. Gurdak, San Francisco State University, Department of Earth \& Climate Sciences, San

6 Francisco, United States

7 Marc Leblanc, University of Avignon-INRA, Hydrogeology Laboratory, UMR EMMAH,

8 Avignon, France

9 Guillaume Favreau, IRD, UMR HydroSciences, University of Montpellier, Montpellier, France;

10 IRD, University of Grenoble-Alpes, CNRS, Environmental Geosciences Institute, Grenoble,

11 France

12 Nienke Ansems, International Groundwater Resources Assessment Centre (IGRAC), Delft, The

13 Netherlands

14 Jac Van der Gun, Van der Gun Hydro-Consulting, The Netherlands

15 Cheikh B. Gaye, University Cheikh Anta Diop, Department of Geology, Dakar, Senegal

16 Alice Aureli, UNESCO International Hydrological Programme (IHP), Paris, France

${ }^{1}$ Correspondence author:; Email: t.carvalho-resende@unesco.org ; Tel: +33 145681835 
19 Key words: GRACE, climate change, groundwater management, groundwater storage, Sub-

20 Saharan Africa

\section{Abstract}

23 The links between climate variability, depicted by times series of oceanic indices, and changes in

24 total water and groundwater storage are investigated across nine large aquifer basins of the

25 African continent. The Gravity Recovery and Climate Experiment (GRACE) mission's

26 observations represent a remarkable tool that can provide insight into the dynamics of terrestrial

27 hydrology in areas where direct in-situ observations are limited. In order to evaluate the impact

28 of inter-annual and multi-decadal climate variability on groundwater resources, this study

29 assesses the relationship between synoptic controls on climate and total water storage estimates

30 from (i) GRACE from 2002 to 2013 and (ii) a two-variables climate-driven model that is able to

31 reconstruct past storage changes from 1982 to 2011. The estimates are then compared to time

32 series of groundwater levels to show the extent to which total water storage covaries with

33 groundwater storage. Results indicate that rainfall patterns associated with the El Niño Southern

34 Oscillation (ENSO) are the main driver of inter-annual groundwater storage changes, whereas

35 the Atlantic Multi-Decadal Oscillation (AMO) plays a significant role in decadal to multi-

36 decadal variability. The combined effect of ENSO and AMO could trigger significant changes in

37 recharge to the aquifers and groundwater storage, in particular in the Sahel. These findings could 
help decision-makers prepare more effective climate-change adaptation plans at both national

39 and transboundary levels.

NOTE TO COPYEDITOR - PLEASE INSERT THE FOLLOWING AS A FIRST-PAGE

42 FOOTNOTE:

43 This article is part of the topical collection "Determining groundwater sustainability from long-

44 term piezometry in Sub-Saharan Africa”

\section{Introduction}

49 Africa faces major water resources management challenges, largely because water is unevenly

50 distributed over the continent and over time. About $64 \%$ of the population rely on limited and

51 highly variable amounts of water, and $25 \%$ of the population experience difficulties in water use

52 due to accessibility or mobilizations issues (e.g. water infrastructure, flow controls, costs)

53 (Vorosmarty et al., 2005). As a result of rapid population growth and higher industrial activity,

54 water demand in Africa is projected to more than double by the end of the $21^{\text {st }}$ century (Wada

55 and Bierkens, 2014), which may compromise the future livelihoods of millions of people and

56 their living standards. Global climate change and variability is expected to exacerbate this issue

57 as it will bring more extreme climate conditions such as droughts (Prudhomme et al., 2014;

58 Trenberth et al., 2014; Malherbe et al., 2016). Groundwater plays an important role in society's

59 adaptation to climate change and variability, especially because it is more resilient to the effects

60 of climate change than surface water (Green et al., 2011; Treidel et al., 2012; Van der Gun, 2012;

61 Taylor et al., 2013a). Groundwater's unique buffer capacity provides a major strength to reduce

62 the risk of temporary water shortage, and to create conditions for survival in areas were climate

63 change is expected to cause water stress (Falkenmark, 2013). 
64 An estimated $75 \%$ or more of Africans use groundwater as their main source of drinking water

65 (UNEP, 2010), particularly in rural areas that rely on low-cost dug wells and boreholes. There is

66 very limited reliable and comprehensive statistics on groundwater use in Africa, but previous

67 assessments indicate an underutilized potential to support irrigated agriculture as most farming in

68 Africa is currently rainfed (Wani et al., 2009). Groundwater is over-exploited for irrigation in

69 many parts of the world (Famiglietti, 2014; Konikow 2015) including Asia where 14\% of

70 cultivated land is irrigated with groundwater (Siebert et al., 2010) but in Africa 1\% of the

71 cultivated land (about $2 \times 10^{6}$ hectares) is irrigated with groundwater (Altchenko and Villholth,

72 2015). In contrast to other regions in the world such as Western Mexico, the High Plains in the

73 central U.S., the Middle East, North-East Pakistan, North-West India, and North-East China,

74 most of Sub-Saharan Africa has not yet experienced the "groundwater crisis" (Famiglietti, 2014)

75 caused by the widespread over-abstraction of groundwater to support large-scale agriculture.

76 Moreover, some major African aquifers tend to coincide with areas of relatively lower

77 population density and water demand (e.g. the Sahel aquifer Basins, the Congo Basin in Central

78 Africa, and the Kalahari Basins in Southern Africa) (Foster et al., 2006; Wada et al., 2010;

79 Gleeson et al., 2012; MacDonald et al., 2012). Many African countries and/or joint bodies in

80 charge of implementing transboundary water agreements thus have an opportunity to anticipate

81 future groundwater use and management challenges through planning, sustainable utilization,

82 and effective protection of groundwater resources (Tuinhof et al., 2011; Gorelick and Zheng,

83 2015).

84 However, the development of long-term effective and reliable groundwater management

85 strategies for coping with water scarcity threats and climate variability and change in Africa is

86 undermined by the lack of adequate data for decision-making (Bates et al., 2008). In recent 
87 years, there has been a substantial decline in hydrometeorological data collection and 88 management in Africa (Houghton-Carr and Fry, 2006; Robins et al., 2006). Decades ago, Africa

89 had a relatively dense network of stations to measure rainfall, temperature and other weather 90 data, but some weather centres have aged badly because of reductions in budgets for field 91 maintenance and inspection, and many of these stations are no longer operating (Giles, 2005).

92 The current density of hydrometeorological stations in Africa is eight times lower than the

93 minimum recommended by the World Meteorological Organization (WMO, 1996). Many

94 governments have a limited ability to collect the data needed for long-term water resources

95 management, and current efforts have mainly focused on rainfall and river flow data collection.

96 As a result, most African countries lack groundwater-monitoring stations and this limits the

97 understanding of the response of groundwater to human and natural conditions (Gaye and

98 Tindimugaya, 2012).

99 Over the last decade, significant advances in the remote sensing techniques have led to a more 100 complete overview of the water cycle at the global scale. Launched in March 2002, the Gravity 101 Recovery and Climate Experiment (GRACE) is the first satellite mission able to provide global 102 observations of terrestrial water storage changes ( $\Delta$ TWS) (Richey et al., 2015; Chen et al., 2016).

103 Given that the dynamics of groundwater are affected by inter-annual to multi-decadal climate 104 variability (Gurdak et al., 2007; Kuss and Gurdak, 2014), longer observations than GRACE's 105 current 15 year record (2002 to 2017) are desirable to better evaluate the past and current 106 evolution of groundwater resources, as well as to provide pointers for the future.

107 To overcome GRACE's time frame limitation and the lack of adequate long-term piezometry 108 data, this study used an approach to reconstruct past water storage variations in major aquifers 109 across Africa through a climate-driven model using precipitation and actual evapotranspiration 
110 data from global datasets over the period of 1982 to 2011. Validation of the results is carried out

111 by comparing the results of modeled total water storage changes $\left(\Delta \mathrm{TWS}_{\mathrm{MODEL}}\right)$ with GRACE-

112 based total water storage changes ( $\Delta$ TWS $\left._{\text {GRACE}}\right)$ estimates from 2002 to 2013 . The model and

113 GRACE-based estimates are then compared to long-term piezometry measurements to show the

114 extent to which total water storage changes covary with observed groundwater storage changes

$115\left(\triangle \mathrm{GWS} \mathrm{SBSERVED}_{\mathrm{O}}\right)$. Using this approach also allows one to quantify teleconnections between total 116 water and groundwater storage changes with global-scale climatic oscillations such as the El 117 Niño Southern Oscillation (ENSO), North Atlantic Oscillation (NAO), and Atlantic Multidecadal 118 Oscillation (AMO).

119 Acronyms and abbreviations are given in the Appendix.

120

121 2. Background

122 2.1. Study areas

123 Nine large aquifer systems in Africa were selected for this study on the basis of hydrogeological,

124 climate and governance conditions as presented in Table 1 and Figure 1.

125 The distribution of aquifers in Africa is now reasonably mapped following long-term 126 programmes launched in the 1960s by national and international agencies and supported 127 variously by UNESCO, IAEA, and British, French, German and Dutch technical assistance. 128 These efforts were subsequently integrated by the International Association of Hydrogeologists 129 (IAH)/UNESCO/BGR WHYMAP Africa Groundwater Resources Map in 2008, which was the 130 baseline for the first quantitative maps of groundwater resources in Africa (MacDonald et al., 131 2012). Approximately 45\% of the African land surface is underlain by large sedimentary basins 
132 hosting relatively homogeneous aquifers that may offer good conditions for groundwater

133 abstraction. Approximately $11 \%$ of the land has a geologically complex structure, highly

134 productive aquifers in heterogeneous folded or faulted regions in close vicinity to non-aquifers.

135 Almost half of the territory (44\%) consists of regions with only limited groundwater resources, 136 generally in local and shallow aquifers in weathered crystalline bedrock or alluvial deposits that 137 locally may be productive (BGR and UNESCO, 2008; Maurice et al., 2018).

138 With regards to storage, a considerable proportion of Africa's groundwater resources is located 139 in the large sedimentary basins in (semi)arid zones (e.g. North Africa, Sahel, and the Kalahari 140 and Karoo basins in Southern Africa) and tropical zones (e.g. the Congo Basin in Central Africa)

141 (MacDonald et al., 2012). These basins usually contain multi-layered aquifer systems with major 142 alluvial formations forming shallow unconsolidated aquifers underlain by consolidated 143 sedimentary rocks forming deeper aquifers. Even in semi-arid parts of Africa the shallow 144 unconsolidated aquifers can be recharged in response to episodic storm events, climate 145 oscillations, and land-use change (Taylor et al. 2009, 2013b). In the Sahara/Sahel aquifers, 146 isotope and hydrochemical investigations have revealed that recharge mainly occurs by direct 147 infiltration of rainwater or by river/surface water interaction as in the case of the Senegal and 148 Niger Rivers (Diaw et al., 2012; Nazoumou et al., 2015; Abdou Babaye et al., 2018). Stable and 149 radioactive isotopes contents in shallow aquifers confirm the presence of modern infiltration 150 water (Lapworth et al., 2013; Zouari, 2015). Recharge rate over these areas are usually low and 151 range from 0.1 to $5 \%$ of annual precipitation (Scanlon et al., 2006). The recharge mechanisms 152 and dynamics of the deeper aquifers is still uncertain. Data from the Sahara/Sahel tend to exhibit 153 piston-flow behavior (i.e. new water "pushing” old water downwards). Depleted stable isotopes 154 contents observed in some aquifers (Taoudeni and Iullemmeden basins) suggests the presence of 
155 palaeoclimatic water or old-recent mixed groundwater (Fontes et al., 1991; Zouari, 2015).

156 However, the deeper aquifers can be considered as not being actively recharged as most of the

157 recharge dates back to more than 5000 years ago (Edmunds, 2008).

158 Most of these aquifers located in large sedimentary basins are transboundary. More than 75

159 transboundary aquifers have been identified in Africa, but as more information and knowledge

160 becomes available this number is likely to increase (IGRAC-UNESCO, 2015). The identified

161 transboundary aquifers represent approximately $42 \%$ of African continental land area and $30 \%$

162 of the population. Arrangements for the management of these transboundary aquifers remain

163 insufficiently developed as groundwater has been traditionally considered a national matter. Only

164 three transboundary aquifers are under an operational agreement, namely the Nubian Sandstone

165 Aquifer System (NSAS), the North-Western Sahara Aquifer System (NWSAS), and the

166 Stampriet Transboundary Aquifer System (STAS). A Memorandum of Understanding was

167 signed in 2014 for the establishment of a consultation mechanism for the Iullemmeden,

168 Taoudeni/Tanezrouft Aquifer System (ITTAS) but has not entered into force yet. Africa is

169 however the continent with the highest proportion of transboundary surface water catchments

170 under an operational arrangement (Meyer, 2016; UNESCO and UNECE, 2017). Given that

171 aquifers and river/lake basins do not necessarily coincide, the most appropriate body to oversee

172 the management of a transboundary aquifer may not necessarily be a river or lake basin

173 organization (if existent). However, these arrangements and institutions could play a crucial role

174 in promoting cooperation over transboundary aquifers through action programmes. 
178 Exchanges between the Earth's atmosphere, oceans, cryosphere and continental hydrology give 179 rise to some natural climate fluctuations, of various periodicities. Some of the most important 180 global-scale climate oscillations on interannual to multidecadal timescales that influence local 181 water resources include the El Niño Southern Oscillation (ENSO), North Atlantic Oscillation 182 (NAO), Pacific Decadal Oscillation (PDO), and Atlantic Multidecadal Oscillation (AMO). These 183 natural climate oscillations are monitored using scalar-valued indices, which characterize 184 positive, negative, and neutral phases of a climate variability mode and to identify the strength of 185 these phases.

186 ENSO is considered as the most important pattern of natural interannual climate variability on 187 Earth (Palmer and Anderson, 1994). It is a coupled ocean-atmospheric phenomenon that has 188 interannual variability with irregular 2- to 7-year cycles between the warm (El Niño) and cold 189 (La Niña) phases that has been occurring for at least the past 700 years (Li et al., 2013). El Niño 190 is characterized by stronger than average sea surface temperatures in the central and eastern 191 equatorial Pacific Ocean, reduced strength of the easterly trade winds in the Tropical Pacific, and 192 an eastward shift in the region of intense tropical rainfall. La Niña is characterized by the 193 opposite - cooler than average sea surface temperatures, stronger than normal easterly trade 194 winds, and a westward shift in the region of intense tropical rainfall. Three very strong El Niño 195 events have occurred since the early 1980s, i.e. 1982-1983, 1997-1998, and more recently 2015196 2016. Although ENSO is centered in the tropics, the changes associated with El Niño and La 197 Niña events affect climate around the world. ENSO’s influence upon annual rainfall levels have 198 been reported all across Africa, particularly in Southern Africa (Manatsa et al., 2011). Droughts 
occur most of the time during the warm phase of ENSO (Masih et al., 2014). On the other hand,

200 the trend to more La Niña-like conditions since 2000 is a likely contributing factor driving the

201 increase in Southern Africa rainfall (Maidment et al, 2015). As compared to the other African

202 regions, the climate of Central Africa and its variability has been the subject of very few studies.

203 The few existing studies suggest that there is not a significant relationship between ENSO and

204 precipitation in Central Africa (Philippon et al., 2012; Taylor et al., 2013b). ENSO has also been

205 linked to the devastating droughts of the 1970s and 1980s in the Sahel (e.g. Giannini et al.,

206 2003). Drier (wetter) decades in the Sahel are usually correlated with El Niño (La Niña) events

207 (e.g. Nicholson and Selato, 2000; Janicot et al., 2011). Several different ENSO indices have

208 developed over time, but the Multivariate ENSO Index (MEI) is favored over other indices

209 because it combines the significant features of all observed surface fields in the tropical Pacific.

210 MEI monthly values were obtained from the NOAA Earth System Research Laboratory (NOAA, 211 2017).

212 The PDO is often described as a long-lived El Niño-like pattern of Pacific climate variability

213 (Zhang et al. 1997). The PDO index is based upon patterns of variation in sea surface

214 temperature of the North Pacific Ocean with warm and cold phases that can persist for 20-30

215 years. Unlike ENSO, the PDO is not a single physical mode of ocean variability, but rather the

216 sum of several processes with different dynamic origins. The PDO monthly values were obtained

217 from the NOAA Earth System Research Laboratory database (NOAA, 2017).

218 The NAO represents a north-south oscillation atmospheric mass between the Icelandic low-

219 pressure system and the Azores high-pressure system. The positive phase of the NAO reflects

220 below-normal surface pressure over the Icelandic to Arctic regions and above-normal surface 
221 pressure over the subtropical Atlantic. The negative phase reflects the opposite. The NAO

222 exhibits considerable interseasonal, interannual and multidecadal variability with irregular 1- to

223 24-year cycles (Hurrell 1995, Chelliah and Bell 2005), but has a dominant quasiperiod

224 oscillation of 3 to 6 years and a less significant 8 to 10 year mode (Hurrell et al. 2003). The NAO

225 is among the known modes of natural variability influencing North Africa precipitation on a

226 variety of time-scales, especially in winter and early spring. Drier (wetter) decades in North

227 Africa largely correspond to positive (negative) NAO phase (Lopez-Moreno et al., 2011).

228 Correlations are however particularly stronger for negative NAO phases (Donat et al., 2014). For

229 example, the negative phase of the NAO from the mid-1950s to late 1970s indicates relatively

230 wet conditions with a gradual shift towards drier conditions in the early 1970s. Recent years have

231 also been considered wetter. NAO monthly values were obtained from the NOAA Earth System

232 Research Laboratory database (NOAA, 2017).

233 The AMO is an index of sea surface temperature over the North Atlantic Ocean (quasi-period 234 cycles of roughly 50 to 70 years) with negative and positive phases that may last for 20-40 years 235 each and lead to differences of about $15^{\circ} \mathrm{C}$ between extremes. Paleoclimatologic studies have 236 confirmed that these changes have been occurring over the past 8000 years (Knudsen et al., 237 2011). The AMO was in positive phases from 1860 to 1880 and 1930 to 1960, and in negative 238 phases from 1905 to 1925 and 1970 to 1990. The AMO flipped to a positive phase in the mid239 1990s and it is believed that the AMO is gradually moving to a negative phase (McCarthy et al., 240 2015). Higher rainfall over the Sahel is associated to positive phases of the AMO (Diatta and 241 Fink, 2014), while the opposite occurs in the Gulf of Guinea (Mohino et al., 2011). The AMO 242 monthly values were obtained from the NOAA Earth System Research Laboratory database 243 (NOAA, 2017). 
244 The interaction of climate variability modes can enhance or diminish certain climatic forcings on

245 local hydrologic processes (Hanson et al. 2004). When El Niño (La Niña) occurs with the warm

246 (cold) PDO phase, rainfall tends to increase over the Sahara to the Gulf of Guinea and Southern

247 Africa, while the opposite occurs in the Horn of Africa (Wang et al., 2014). Several studies

248 suggest that the AMO modulates the ENSO and NAO variability (Dong et al. 2006; Dong and

249 Sutton 2007; Timmermann et al. 2007; Zhang et al., 2012; García-García and Ummenhofer, 250 2015). Strengthened (weakened) La Niña effects coincide with a positive (negative) phase of the

251 AMO (Geng et al., 2016). In the Sahel (Lake Chad), the severe impact of droughts of the 1970s

252 and 1980s are tied to the combined effect of the negative phase of the AMO and El Niño events

253 (Okonkwo et al., 2015). Finally, ENSO and AMO are well-known climate teleconnections that

254 have been associated with extreme rainfall variability in Western/Central Africa (Ndehedehe et 255 al., 2017). An inverse relationship exists between the AMO and the NAO decadal tendencies. 256 When the AMO is negative, NAO tends more often to the positive state. Statistical analyses over 257 the $20^{\text {th }}$ century suggest that the AMO precedes NAO by 10-15 years (Peings and Magnusdottir, 258 2014). These findings provide an interesting possibility of decadal forecasting.

\section{3.1. GRACE observations}

262 There has been great interest in the use of GRACE satellites to monitor changes in water storage, 263 especially in regions with limited ground-based data such as Africa (Henry et al., 2011; Ramilien

264 et al., 2014; Richey et al., 2015; Chen et al., 2016; Hassan and Jin, 2016; Rateb et al., 2017).

265 GRACE satellites provide a spatially filtered image of real TWS that needs to be processed to 
266 produce information on changes in TWS. There are generally three approaches to process

267 GRACE total water storage change signals: the scaling factor approach, the additive correction

268 approach and the multiplicative correction approach. The validation of GRACE-based estimates

269 is challenging because results can differ by up to $100 \%$ depending on which processing approach

270 is used, in particular over i) (semi-)arid areas, ii) areas with intensive irrigation, and iii) relative

271 small basins (i.e. $\leq 200,000 \mathrm{~km}^{2}$ ) for which the additive correction approach may be more

272 appropriate (Long et al., 2015). It is thus imperative to compare GRACE-based estimates with

273 ground-based data to assess their validity.

274 Considering that most of the studied aquifer systems are located in arid and semi-arid areas, the 275 additive correction approach as presented by Longuevergne et al. (2010) to provide total water 276 storage estimates from 2002-2013 at a monthly basis has been used. This is based upon monthly 277 spherical harmonic (SH) gravity field solutions R05 monthly data from CSR (Center for Space 278 Research, Univ. of Texas at Austin, US), truncated at degree and order 60 (Bettadpur, 2007), 279 including a destriping filter (Swenson and Wahr, 2006) and additional $300 \mathrm{~km}$ Gaussian 280 smoothing. Alternate methods for leakage corrections encompass the mascon-type approach. The 281 basic difference between spherical harmonics ( $\mathrm{SH})$ and mascons is that $\mathrm{SH}$ solutions are global 282 whereas mascons can be applied at regional to global scales. A recent study has shown that 283 although long-term trends for $\mathrm{SH}$ are lower than those for mascons, they remain highly 284 correlated (Scanlon et al., 2016). The method used for detrending total water storage time series 285 is fitting and removing a trend model consisting of a long-term linear and seasonal cycles by 286 using linear regression (Sun et al., 2017). Results are compared with groundwater changes from 287 piezometry $\left(\Delta \mathrm{GWS}_{\mathrm{OBSERVED}}\right)$ and modeled changes in total water storage ( $\left.\triangle \mathrm{TWS} \mathrm{S}_{\mathrm{MODEL}}\right)$ in order 288 to identify any long-term covariance. Particular attention is given to aquifer systems whose area 
289 is below the limit of the GRACE footprint (Karoo Sedimentary, Stampriet Transboundary

290 Aquifer System and Volta Basin Aquifer).

293 Trends during the GRACE era (2002 - 2017) are dominated by internal climate variability (i.e., 294 arising from interactions and chaotic variability within the climate system, particularly in 295 rainfall) rather than by the forced response (i.e., driven primarily by human induced changes in 296 atmospheric composition) (Fasullo et al., 2016). Key to understanding reported changes during 297 the GRACE record is quantifying the character of internal climate modes. The GRACE era only 298 covers a very limited number of climatic oscillation cycles as some modes like the AMO, PDO, 299 and NAO have oscillation periods longer than the GRACE observation record. Several studies 300 indicate that low-frequency cycles like AMO and PDO are particularly influential in modulating 301 high-frequency cycles such as ENSO. To bridge this gap, there is a need to extend the GRACE 302 timeframe to the "past" using a model that is able to reconstruct the interannual to decadal 303 climate-driven changes in water storage. A climate-driven model to estimate long-term water 304 storage dynamics, independent from GRACE data, was developed and applied at the aquifer 305 scale.

306 According to MacDonald et al. (2012), groundwater development stress is relatively low in most 307 of the large African aquifers with renewable groundwater resources. This suggests that changes 308 in groundwater storage in such aquifers tend to be dominated by climatic variations. For that 309 reason, human influences (such as abstraction and land-use changes) are neglected in the simple 310 simulation model. This model is based on elaboration of the general water balance equation: 


$$
\frac{d \mathrm{TWS}}{d t}=P-E-R \quad(\text { Eq. } 1)
$$

312 where $P$ is precipitation, $E$ is actual evapotranspiration, $R$ is runoff (or discharge at the basin

313 outlet), and TWS is total water storage (sum of water stored in vegetation, ice, snow, lakes and 314 streams, soil moisture and groundwater). All components are given in millimetres per month. 315 Mean precipitation and actual evapotranspiration were computed by averaging data available 316 from global datasets with spatial resolutions of $0.5^{\circ}$ x $0.5^{\circ}$ at aquifer scale from 1982 to 2011 317 (Global Precipitation Climatology Centre dataset for precipitation (Becker et al., 2013), and Max 318 Planck Institute dataset for actual evapotranspiration) (Jung et al., 2010). These datasets were 319 selected because of their capability to capture the regionally averaged seasonal cycles (Mueller et 320 al., 2011; Sun et al., 2018).

321 Integration of Eq. 1 gives:

$$
\Delta \mathrm{TWS}=\int P d t-\int E d t-\int R d t
$$

$323 \Delta$ TWS is the change of total water storage over the time interval of integration, thus it includes 324 the changes in water stored in vegetation, snow, ice, lakes and streams, soil moisture and 325 groundwater. Integration over time of $P, E$, and $R$ will generate a long-term trend in $\Delta \mathrm{TWS}$, 326 which is attributed to integration of systematic errors in these variables. Unbiased datasets are 327 therefore required. Considering that $P$ is the dominant factor controlling long-term variations of $328 E$, and $R$, it is assumed that runoff is constant over time, i.e. contribution to storage as a linear 329 trend (Bouwer et al., 2006; Liu et al., 2013). By doing so, when estimating storage changes by 330 integration of $R$, a long-term trend related to runoff is removed. Thus, Eq. 2 becomes:

$$
\Delta \mathrm{TWS}_{\mathrm{MODEL}}=\int P d t-\int E d t-\int R d t \approx \operatorname{detrend}\left(\int P d t-\int E d t\right)
$$

332 In absence of detailed field data on all these storage components it is difficult to isolate the 333 change in groundwater storage ( $\Delta \mathrm{GWS}$ ), but under certain circumstances - to be judged by the 
334 modeller- it is plausible that $\Delta \mathrm{GWS}$ is nearly equal to $\Delta \mathrm{TWS} \mathrm{S}_{\mathrm{MODEL}}$. Such circumstances may, for

335 instance, apply to relatively long integration intervals (several years) in arid and semi-arid

336 regions where the assumed combined non-groundwater storage capacity is small compared to the

337 simulated change in total water storage $\left(\Delta \mathrm{TWS}_{\mathrm{MODEL}}\right)$.

\subsection{Ground-based measurements}

340 Due to the general lack of continuous long-term groundwater level data, the selection of records

341 for the validation of GRACE-based estimates was done based on the limited data available in

342 literature and their representativeness. The selected records are usually located no farther than 20

$343 \mathrm{~km}$ from surface water bodies (e.g. river, lake, oued) and tap shallow unconfined aquifers. The

344 records provide groundwater levels at a monthly basis for different periods ranging from 5 to 20

345 years (Figure 2 and Table 2). In order to compare piezometry with total water storage, long-term

346 groundwater level data were detrended by using the MATLAB function detrend that substracts

347 the mean or a best-fit line (in the least-square sense) from data. If the data do have a trend,

348 detrending forces the mean to zero and reduces overall variation. 
353 Wavelet transforms to analyze teleconnections between groundwater level, GRACE-based

354 estimates, climate-driven model and climate indices time series were used both in amplitude and

355 frequency. A MATLAB script developed by Grinsted et al. (2004) that enables doing continuous

356 wavelet transform (CWT), cross wavelet transform (XWT) and wavelet coherence (WTC) plots

357 was applied. CWT expands the time series into time frequency space, XWT finds regions in time

358 frequency space where the time series show high common power and WTC finds regions in time

359 frequency space where the two time series co-vary (but does not necessarily have high power)

360 (Torrence and Compo, 1998; Labat et al., 2000; Grinsted et al., 2004; Labat 2005; 2008; Holman

361 et al., 2011). Although the three methodological steps described previously were necessarily

362 followed, the presentation of the results and discussion focuses on the WTC plots. High

363 correlation between time series is indicated by light yellow zones. The arrows $\rightarrow$ and $\leftarrow$ in zones

364 of the WTC figures indicate the positive (in-phase) and negative (anti-phase) relationships

365 between two time-series, respectively. Meanwhile, the arrows $\downarrow$ and $\uparrow$ show that time series 1

366 lags time series 2 by $90^{\circ}$. The interpretation of lags in these zones can be however challenging

367 and should be done carefully as a lead of $90^{\circ}$ can also be interpreted as a lag of $270^{\circ}$ or a lag of

$36890^{\circ}$ relative to the anti-phase (opposite sign). A good indication to support that there is a

369 connection and link between times series is that the phase-arrows generally point only in one

370 direction for a given wavelength.

\section{$372 \quad$ 4. Results and discussion}

373 4.1. Evaluation of GRACE-based and climate-driven model estimates 
374 GRACE-based and climate-driven model total water storage changes $\left(\Delta T_{W} S_{\text {GRACE }}\right.$ and $375 \Delta \mathrm{TWS}_{\mathrm{MODEL}}$, respectively) are compared to groundwater levels in the studied aquifers to assess 376 to what extent they covary with $\triangle$ GWS OBSERVED. All data were detrended in order to focus the 377 analysis on the fluctuations in the data. However, it is worth mentioning that total water storage 378 time series are nonlinear, nonstationary and tend to vary at multiple temporal scales, making 379 filtering and detrending of total water storage a nontrivial task (Sun et al., 2017). The data 380 were further normalized based on the mean and standard deviation of each dataset in order to 381 provide a benchmark and comparison basis. Results suggest that changes in total water storage 382 estimates describe generally well groundwater-level dynamics (Figure 3). These results are 383 further verified by wavelet transform analysis that indicate that there exists a high correlation 384 between GRACE-based and climate-driven model water storage estimates and groundwater level 385 both at intra-annual and inter-annual scale (Figure 4a and Figure 4b). Given that comparison is 386 done with groundwater level records from shallow boreholes that are located in the vicinity of 387 surface water bodies (usually $<20 \mathrm{~km}$ ) which are likely to have a strong surface water / 388 groundwater interaction, it is fair to conclude that $\Delta$ TWS $_{\text {GRACE, }} \Delta \mathrm{TWS}_{\mathrm{MODEL}}$ and $389 \Delta \mathrm{GWS}_{\mathrm{OBSERVED}}$ representative of groundwater fluctuations in shallow unconfined aquifers are 390 strongly correlated. This could also suggest that storage changes in deep aquifers are limited, 391 thus supporting the assumptions that they are not being actively recharged and that they are 392 exploited still largely at low rates. The near-synchronous signals of groundwater levels and the 393 climate-driven model water storage estimates (Figure 3, Figure 4a and Figure 4b) reveal that 394 shallow aquifers are highly responsive to rainfall temporal patterns, and reinforce the concept 395 that natural climate variability, in particular changes in precipitation, considerably contributes to 396 groundwater storage changes. 


\section{INSERT FIGURE 4a HERE}

INSERT FIGURE 4b HERE

401 Results of the model allowed identifying four different types of groundwater storage dynamics 402 that are largely correlated with African climate zones. The model indicates that the North403 Western Sahara Aquifer System (NWSAS) located in Northern Africa had a decrease in storage 404 from early-1980s to late-1980s, an increase in early 1990s followed by a decrease from mid405 1990s to mid-2000s, an increase in mid-2000s, and a decrease since then (Figure 5). This is in 406 relatively good agreement with rainfall pattern and shallow groundwater fluctuation in the 407 vicinity of oueds in the Ouargla Plain in Algeria/Tunisia (Bellaoueur, 2008) and central Tunisia 408 (Massuel and Riaux, 2017) (Figure 2). The model's water storage increase in mid-2000s also 409 supports the assumption that the shallow aquifers (including outcrops of the deep aquifers) of the 410 North-Western Sahara Aquifer System are receiving a fraction of modern water as recharge from 411 infiltration of rainfall coming from the Sahara Atlas Mountains in Algeria and the Dahar and 412 Nafusa Mountains in Tunisia and Lybia (Baba-Sy, 2005; Al-Gamal, 2011). It should be noted 413 however that groundwater abstraction in the NWSAS has steeply risen over the past decades 414 because of tapping confined aquifers by drilling deep boreholes in the 1980s for water supply 415 and irrigation schemes (OSS, 2003). These boreholes have had very little maintenance since they 416 were drilled and recently observed water table rises in shallow aquifers could be locally 417 influenced by upward leakage through corroded borehole casing (Messekher et al., 2012). 
419 The aquifers located in the Sahel (Nubian Sandstone Aquifer System, Lake Chad Basin, Irhazer420 Iullemmeden Basin, and Senegalo-Mauritanian Basin) have a similar multi-decadal behavior, 421 which is characterized by a significant decrease in groundwater storage from early-1980s to mid422 1990s followed by a partial recovery (Figure 6). As rainfall in the Sahel has generally increased 423 since mid-1990s, this result proves to be in good agreement with the observations from 424 piezometry indicating that the water table has risen since the mid-1980s in large parts of the 425 central Sahel (Favreau et al., 2009, 2012). It also supports the assumption that rainfall infiltration 426 is a primary source of recharge, though recharge from surface water bodies such as the Niger and 427 the Nile Rivers is non-negligible and limited to the vicinities of the rivers (perennial and 428 seasonal) and endoreic ponds (Nazoumou et al., 2015; Ngounou-Ngatcha et al., 2015). Aquifers 429 located in the tropics (Volta Basin and Karoo Carbonate) show an opposite behavior although 430 changes are not as pronounced as in the aquifers in the Sahel (Figure 7). This result is in line 431 with recent observations that indicate a drying trend in central equatorial Africa (west of 432 Albertine Rift) (Diem et al., 2014) and over Guinea regions, such as Benin and Nigeria (Bamba 433 et al., 2015).

\section{INSERT FIGURE 6 HERE}

436 Contrary to the aquifers in the Sahel, the aquifers in Southern Africa do not show a particular 437 multi-decadal pattern, but rather a strong inter-annual pattern. The model indicates a decrease in 438 storage from early-1980s to late-1980s, an increase in late-1980s/early-1990s, a decrease from 
439 early-1990s to mid-1990s/late-1990s, an increase in late-1990s/early-2000s, a decrease from

440 early-2000s to mid-2000s, and an increase since mid-2000s (Figure 8). This result is consistent

441 with studies that revealed that long-term rainfall trends in Southern Africa are weak but exhibit

442 an increased variability since 1970 (Richard et al., 2001).

444 4.2. Groundwater storage variability and its association with climate teleconnections

445 Groundwater storage variability and its association with climate teleconnections is studied by 446 applying wavelet transforms between simulated changes in total water storage $\left(\Delta \mathrm{TWS}_{\mathrm{MODEL}}\right)$ 447 and climate indices (NAO, ENSO, and AMO). In Northern Africa, groundwater storage appears 448 to be correlated to NAO (Figure 5c). WTC reveals three regions with high coherence (good 449 correlation), i.e. 6-8 year band from 1990 to 1995 (Box 1 in Figure 5c), 1-2 year band from mid450 1990s to mid-2000s (Box 2 in Figure 5c), and 2-3 year band from mid-2000s onwards (Box 3 in 451 Figure 5c), which indicates that NAO exerts an influence on changes in groundwater storage. 452 Positive (negative) NAO phase largely correspond to decreasing (increasing) groundwater 453 storage. The results confirm that inter-annual correlations tend to be stronger for negative NAO 454 phases (Box 2 and Box 3 in Figure 5c). This has been particularly true since the AMO shift back 455 to a positive phase in mid-1990s, thus suggesting that the AMO exerts a low-frequency 456 modulating influence on groundwater storage changes.

457 The influence of the AMO on groundwater storage appears to be much more direct in the Sahel.

458 The AMO appears to exert a multi-decadal influence as a positive (negative) phase largely 459 corresponds to increasing (decreasing) aquifer storage (Figure 6). For instance, all aquifers in the 
460 Sahel show a significant modeled decrease in aquifer storage during a negative phase of the 461 AMO from the early-1980s to mid-1990s followed by an increase in groundwater storage during 462 a positive phase of the AMO since the mid-1990s. Mega-droughts in the Sahel are considered to 463 be linked to the combined effect of the negative phase of the AMO and El Niño events 464 (Shanahan et al., 2009; Masih et al., 2014). Such combination also appears to have a substantial 465 adverse effect on groundwater storage as it could potentially result, depending on recharge 466 processes in play, in both reduced recharge to the aquifers and in water level declines attributed 467 to climate-induced pumping (Gurdak 2017; Russo and Lall 2017). The AMO exerts an opposite 468 influence in the aquifers located in the tropics (Volta Basin and Karoo Carbonate), as positive 469 (negative) phase largely corresponds to (increasing) decreasing groundwater storage (Figure 7).

470 Total water storage and consequently groundwater storage inter-annual variability both in the 471 Sahel and in Equatorial Africa are likely to be impacted by ENSO, as WTC plots for the Nubian 472 Sandstone Aquifer System and the Senegalo-Mauritanian Basin (Figure 9) and for the Volta 473 Basin and Karoo Carbonate Aquifers (Figure 10) reveal several regions with high coherence 474 (good correlation). These regions largely coincide with El Niño events (1982-1983, 1986-1988, 475 1991-1992, and 1997-1998) and La Niña events (1998-2000). A recent study by Siam and Eltahir 476 (2017) revealed a strong correlation between ENSO, rainfall and flow in the Nile basin. El Niño 477 years usually lead to drought conditions, whereas La Niña years are more flood-prone. 478 Considering that recharge of the shallow aquifers mainly occurs by rainfall infiltration and 479 river/surface water interaction, it could be assumed that El Niño (La Niña) years could lead to 480 decreased (increased) groundwater storage. This assumption could be extended to the Sahel 481 and/or Equatorial Africa as similar observations have been found for Lake Chad (Okonkwo et 482 al., 2015), the Senegal and Niger River basins (Diaw et al., 2012; Nazoumou et al., 2015), and 
483 Lake Volta (Owusu et al., 2008). Due to the relative shortage of long-term climate data, any

484 assumption on cause-effect relationship in the correlation results of the model and climate 485 indices in Central Africa is particularly more complex as there has been only a very limited 486 number of studies of the climate of this region (Philippon et al., 2012). Central Africa has the 487 lowest gauge density in sub-Saharan Africa (Washington et al., 2013) and has seen a dramatic 488 decline in the number of rain gauges, especially after 1980s (Asefi-Najafabady and Saatchi, 489 2013, Zhou et al., 2014). Studies diverge in their conclusions in this region. According to Gao et 490 al. (2016), drier conditions are associated with El Niño events while Taylor et al. (2013) suggest 491 that the influence of ENSO varies spatially and studies in has indicated an opposite pattern as El 492 Niño years are associated to increases in recharge generated by heavy rainfall (Taylor et al., 493 2013).

INSERT FIGURE 9 HERE

\section{INSERT FIGURE 10 HERE}

496 WTC plots for the Stampriet Transboundary Aquifer System and the Karoo Sedimentary Aquifer

497 in Southern Africa also reveal important correlation between groundwater storage and ENSO

498 events with El Niño (La Niña) events usually leading to drier (wetter) conditions and decreasing

499 (increasing) water levels (Figure 8). The dynamics of these aquifers are not similar and thus

500 indicates that other climate modes might also be exerting an influence in Southern Africa.

501 Previous studies present clear evidence of the importance of the Indian Ocean Dipole (IOD)

502 index in modulating rainfall variability in Eastern Africa (Taylor et al., 2013b). The IOD has

503 traditionally been linked to ENSO (Marchant et al., 2006; Fan and Liu, 2017). Major ENSO

504 warm (El Niño) events combined with a positive phase of the IOD have led to wet extremes and 
505 significant recharge in the Karoo Sedimentary Aquifer (Figure 11). Conclusions about the 506 correlation between the IOD and groundwater storage changes for the Nubian Aquifer Sandstone

507 System and the Karoo Carbonate Aquifer are more challenging because the influence of IOD 508 varies across the aquifer basin (Awange et al., 2014; Onyutha and Willems, 2017) and because of 509 the lack of data, respectively. INSERT FIGURE 11 HERE

\section{5. Conclusions}

513 A two-variables climate-driven model using precipitation and actual evapotranspiration data 514 from global datasets was developed to reconstruct past total water storage changes in Africa from

5151982 to 2011. Although the model has the important limitation of not considering human 516 influences such as abstraction, land-use changes, and dam management, it offers robust pointers 517 to assess the monthly dynamics of groundwater storage at very little computational cost as 518 model-based total water storage changes $\Delta \mathrm{TWS}_{\mathrm{MODEL}}$ and observed groundwater storage

519 changes $\triangle G W_{\text {OBSERVED }}$ (representative of shallow groundwater fluctuations) are strongly 520 correlated. GRACE-based $\triangle \mathrm{TWS}_{\mathrm{GRACE}}$ estimates are also highly correlated with model-based $521 \Delta \mathrm{TWS}_{\text {MODEL }}$ and $\Delta \mathrm{GWS}_{\mathrm{OBSERVED}}$. As GRACE Follow-On (GRACE-FO) mission is scheduled to 522 be launched in early $2018, \Delta$ TWS $_{\text {GRACE }}$ estimates will thus prove to be a well-founded tool to 523 provide a general overview at basin scale of groundwater storage changes that are associated to 524 shallow groundwater fluctuations and that are likely to have a strong interaction with surface 
525 water. The near-synchronous signals of groundwater levels, GRACE and the climate-driven

526 model estimates reveal that shallow aquifers are highly responsive to rainfall temporal patterns.

527 Obtained results indicate that recharge from rainfall patterns associated to NAO and ENSO are

528 the main drivers of inter-annual groundwater storage changes in Northern Africa and Sub-

529 Saharan Africa, respectively. The AMO plays a significant role in decadal to multi-decadal

530 variability, particularly in the Sahel as positive (negative) AMO phase largely corresponds to

531 increasing (decreasing) groundwater storage. The AMO has been in a positive phase since mid-

532 1990s and as a result, this has contributed to a water table rise in large parts of the Sahel. A

533 change of phase could have an overwhelming impact on surface-water and groundwater

534 resources, as mega-droughts in the early 1980s in the Sahel are tied to the combined effect of a

535 negative phase of the AMO and a positive phase of the ENSO. These devastating droughts could

536 trigger significant groundwater storage changes, resulting in reduced recharge to the shallow

537 aquifers and water level declines attributed to climate-induced pumping from dug-wells and

538 shallow boreholes.

539 The findings of this study could be beneficial to decision-makers and help to adequately prepare

540 effective climate variability and change adaptation plans both at national and transboundary

541 level. National groundwater governance frameworks in Africa usually need either reviewing and

542 upgrading water laws and policies or completing water law with regulations (FAO, 2015).

543 Integrating climate variability aspects into water laws and policies (e.g. drought and flood

544 management plans, provisions for Managed Aquifer Recharge (MAR) schemes), strengthening

545 national meteorological, hydrological and groundwater-monitoring networks, and in particular

546 strengthening links between water decision-makers and meteorological institutions are crucial

547 measures for improving groundwater governance with special reference to climate change. 
Integrated Water Resources Management (IWRM) is now widely accepted by water decision-

549 makers as the way forward for efficient, equitable and sustainable development and management

550 of the world's limited water resources and for coping with conflicting demands (UNESCO,

551 2009). IWRM structures in Africa are rolled out across the continent with the present focus on

552 the establishment of river basin / catchment organizations at national and transboundary level.

553 However, groundwater is still poorly integrated into these organizations' IWRM and climate

554 adaptation plans. MAR is a promising adaptation approach to reduce vulnerability to climate

555 variability and aquifer over-exploitation. Findings from this study illustrate that MAR operations

556 might take advantage of temporal patterns in precipitation to enhance recharge during the

557 corresponding wet phases of ENSO, NAO, and AMO. Institutions in charge of the management

558 of groundwater resources at national and transboundary level, as well as river basin / catchment

559 organizations, should strengthen their support to MAR programs and initiatives to incentivize

560 local water managers to store excess renewable water in aquifers during wet periods which can

561 be used to off-set limited surface-water supplies during dry periods. The findings suggest that

562 preferred periods for artificial recharge are negative phases of the NAO in Northern Africa,

563 positive phases of the AMO in the Sahel, and La Niña years in Southern Africa. Finally, it is

564 worth emphasizing that developing long-term effective and reliable strategies for coping with

565 water scarcity threats and climate variability and change will also have to overcome the fact that

566 there are still large uncertainties and limited adequate data for decision-making. In this regard, it

567 is also important to undertake joint actions in data collection interpretation and reporting as a

568 means to promote inter-basin/inter-aquifer collaboration, to harmonise strategies and promote

569 exchange of experiences. 


\section{References:}

572 Abdou Babaye, M.S., Orban, P., Ousmane, B., Favreau, G., Brouyère, S., Dassargues, A. (2018)

573 Characterisation of recharge mechanisms in a Precambrian basement aquifer in semi-arid south-

574 west Niger. Hydrogeology Journal, https://link.springer.com/article/10.1007/s10040-018-1799-x

575 Al-Gamal, S. (2011) An assessment of recharge possibility to North-Western Sahara Aquifer

576 System (NWSAS) using environmental isotopes. Journal of Hydrology, 398, pp. 184-190,

577 doi:10.1016/j.jhydrol.2010.12.004.

578 Altchenko, Y.; Villholth, K. G. (2015) Mapping irrigation potential from renewable groundwater

579 in Africa - a quantitative hydrological approach, Hydrology and Earth System Sciences, 19, pp.

580 1055-1067, doi:10.5194/hess-19-1055-2015.

581 Asefi-Najafabady, S., Saatchi, S. (2013) Response of African humid tropical forests to recent

582 rainfall anomalies. Philosophical Transactions of the Royal Society B: Biological Sciences,

583 368(1625), 20120306, doi:10.1098/rstb.2012.0306.

584 Awange, J.L., Forootan, E., Kuhn, M., Kusche, J., Heck, B. (2014) Water storage change and

585 climate variability within the Nile Basin between 2002 and 2001. Advances in Water Resources,

586 73, pp. 1-15, doi : 10.1016/j.advwatres.2014.06.010.

587 Baba-Sy, J. (2005) Recharge et paléorecharge du système aquifère du Sahara septentrional, 588 Ph.D. Thesis, Univ. Tunis, Tunisia.

589 Bamba, A., Dieppois, B., Konaré, A., Pellarin, T., Balogun, A., Dessay, N., Kamagaté, B.,

590 Savané, I. and Diédhiou, A. (2015) Changes in Vegetation and Rainfall over West Africa during

591 the Last Three Decades (1981-2010). Atmospheric and Climate Sciences, 5, pp. 367-379,

592 doi:10.4236/acs.2015.54028. 
Bates, B.C., Kundzewicz Z.W., Wu S. and J.P. Palutikof (eds) (2008) Climate Change and

594 Water. Technical Paper of the Intergovernmental Panel on Climate Change, IPCC Secretariat, 595 Geneva, 210 pp.

596 Becker, A., Finger, P., Meyer-Christoffer, A., Rudolf, B., Schamm, K., Schneider, U. and Ziese, 597 M. (2013) A description of the global land-surface precipitation data products of the Global 598 Precipitation Climatology Centre with sample applications including centennial (trend) analysis 599 from 1901-present, Earth System Science Data, 5, pp. 71-99, doi:10.5194/essd-5-71-2013.

600 Bellaoueur, A.A. (2008) Etude hydrogéologique des eaux souterraines de la région de Ouargla 601 soumise à la remontée des eaux de la nappe phréatique et perspectives de solutions palliatives 602 (Sahara Nord-Est Septentrional - Algérie) (Hydrogeological study of groundwater in the Ouargla 603 region subjected to upwelling of the water table and prospects of palliative solutions (North604 Eastern Sahara - Algeria)). MSc. Thesis, Univ. El-Hadj Lakhdar - Batna, Algeria.

605 Bettadpur, S. (2007) Level-2 gravity field product user handbook, GRACE 327-734, GRACE 606 Proj. Cent. For Space Res., Univ. of Texas, Austin.

607 BGR and UNESCO (2008) Groundwater Resources of Africa [map]. World-wide

608 Hydrogeological Mapping and Assessment Programme (WHYMAP).

609 https://www.whymap.org/whymap/EN/Maps_Data/Additional_maps/addimaps_node_en.html.

610 Cited 6 June 2017.

611 Bouwer, L.M., Aerts, J.C., Droogers, P., Dolman, A.J. (2006) Detecting the long-term impacts

612 from climate variability and increasing water consumption on runoff in the Krishna river basin

613 (India), Hydrology and Earth System Sciences, 10, pp. 703-713, doi: 10.5194/hess-10-703-2006.

614 Chelliah, M. and Bell, G.D. (2004) Tropical multidecadal and interannual climate variations in 615 the NCEP-NCAR reanalysis. Journal of Climate, 17, pp. 1777-1803, doi: 10.1175/1520-0442. 
616 Chen, J., Famiglietti, J.S., Scanlon, B.R., Rodell, M. (2016) Groundwater Storage Changes:

617 Present Status from GRACE Observations. Surveys in Geophysics, 37(2), pp. 397 - 417, doi:

618 10.1007/s10712-015-9332-4.

619 Cuthbert, M.O., Gleeson, T., Reynolds, S.C., Bennett, M.R., Newton, A.C., McCormack, C.J. 620 and Ashley, G.M. (2017) Modelling the role of groundwater hydro-refugia in East African

621 hominin evolution and dispersal, Nature Communications, 8, doi:10.1038/ncomms15696.

622 Diatta, S., Fink, A. H. (2014) Statistical relationship between remote climate indices and West

623 African monsoon variability. International Journal of Climatology, 34, pp. 3348-3367,

624 doi:10.1002/joc.3912.

625 Diaw, F., Stichler, W., Mloszewski, P. (2012) Isotopic and geochemical characteristics of 626 groundwater in the Senegal River delta aquifer: implication of recharge and flow regime.

627 Environmental Earth Sciences, 66, 4, pp. 1011-1020, doi: 10.1007/s12655-010-0710-4.

628 Diem, J.E., Ryan, S.J, Hartter, J., Palace, M.W. (2014) Satellite-based rainfall data reveal a

629 recent drying trend in central equatorial Africa. Climatic Change, 126(1-2), pp. 263-272, doi:

630 10.1007/s10584-014-1217-x.

631 Donat, M. G., Peterson, T. C., Brunet, M., King, A.D., Almazroui, M., Kolli, R.K., Boucherf, D., 632 Al-Mulla, A.Y., Nour, A.Y., Aly, A.A., Ali Nada, T.A., Semawi, M.M., Al Dashti, H.A., Salhab, 633 T.G., El Fadli, K.I., Muftah, M.K., Eida, S.D., Badi, W., Driouech, F., El Rhaz, K., Abubaker, 634 M.J.Y., Ghulam, A.S., Erayah, A.S., Mansour, M.B., Alabdouli, W.O., Al Dhanhani, J.S. and Al 635 Shekaili, M .N. (2014) Changes in extreme temperature and precipitation in the Arab region:

636 long-term trends and variability related to ENSO and NAO. International Journal of

637 Climatology, 34, pp. 581-592, doi:10.1002/joc.3707. 
638 Dong, B., Sutton, R.T. (2007) Enhancement of ENSO Variability by a Weakened Atlantic

639 Thermohaline Circulation in a Coupled GCM. Journal of Climate, 20, pp. 4920-4939,

640 doi:10.1175/JCLI4284.1.

641 Dong, B., Sutton, R.T., Scaife, A.A. (2006) Multidecadal modulation of El Niño - Southern

642 Oscillation (ENSO) variance by Atlantic Ocean sea surface temperatures, Geophysical Research

643 Letters, 33, doi:10.1029/ 2006GL025766.

644 Edmunds, W.M. (2008) 'Groundwater in Africa - Palaeowater, climate change and modern

645 recharge' in Adelana S.M.A. and MacDonald A.M. (eds) Applied groundwater research in

646 Africa. IAH Selected Papers in Hydrogeology 13. Amsterdam: Taylor and Francis.

647 El Shazli, Ahmed (2018) Water balance of the Aswan High Dam Reservoir. Ph.D. Thesis, Kiel

648 University.

649 Falkenmark, M. (2013) Adapting to climate change: towards societal water security in dry-

650 climate countries. International Journal of Water Resources Development, 29, pp. 123-136,

651 doi:10.1080/07900627.2012.721714.

652 Famiglietti, J.S. (2014) The global groundwater crisis. Nature Climate Change, 4, pp. 945-948,

653 doi :10.1038/nclimate2425.

654 Fan, L. and Liu, Q. (2017) Indian Ocean Dipole Models Associated with Different Types of

655 ENSO Development. Journal of Climate, 30, pp. 2233-2249, doi: 10.1175/JCLI-D-16-0426.1.

656 FAO (2015) Global Diagnostic on Groundwater Governance (Special edn. For World Water

657 Forum 7). Groundwater Governance - A Global Framework for Action, GEF Groundwater

658 Governance Project. http://www.groundwatergovernance.org. Cited 6 June 2017. 
659 Fasullo, J.T., Lawrence, D.M., Swenson, S.C. (2016) Are GRACE-era Terrestrial Water Trends

660 Driven by Anthropogenic Climate Change? Advances in Meteorology, vol. 2016,

661 doi:10.1155/2016/4830603.

662 Favreau, G., Cappelaere, B., Massuel, S., Leblanc, M., Boucher, M., Boulain, N. and Leduc, C.

663 (2009), Land clearing, climate variability, and water resources increase in semiarid southwest

664 Niger: A review. Water Resources Research, 45, doi:10.1029/2007WR006785.

665 Favreau, G., Nazoumou, Y., Leblanc, M., Guéro, A., Goni, I.B. (2012) Groundwater resources in

666 the Iullemmeden Basin, West Africa. In: Treidel, H., Martin-Bordes, J.L., Gurdak, J.J. (Eds.)

667 Climate Change Effects on Groundwater Resources: A Global Synthesis of Findings and

668 Recommendations”. International Contributions to Hydrogeology, 27, 7, pp. 113-128, CRC

669 Press Inc., Leiden, The Netherlands.

670 Fontes, J.C., Andrew, J.N., Edmunds, W.M., Guerre, A., Travi, Y. (1991) Paelorecharge by the

671 Niger River (Mali) deduced from groundwater geochemistry, Water Resources Research, 27, 2,

672 pp. 199-214, doi:10.1029/90WR01703.

673 Foster, S., Tuinhof, A., Garduño, H. (2006) Groundwater Development in Sub-Saharan Africa: A

674 Strategic Overview of Key Issues and Major Needs. World Bank GWP Associate Program.

675 Sustainable Groundwater Management: Concepts and Tools. Case Profile Collection No. 15.

676 Gao, H., Zhang, S., Fu, R., Li, W. and Dickinson, R.E. (2016) Interannual Variation of the

677 Surface Temperature of Tropical Forests from Satellite Observations. Advances in Meteorology,

678 doi:10.1155/2016/4741390.

679 García-García, D., Ummenhofer, C.C. (2015) Multidecadal variability of the continental

680 precipitation annual amplitude driven by AMO and ENSO, Geophysical Research Letters, 42,

681 pp. 526-535, doi:10.1002/2014GL062451. 
682 Gaye, C.B., Tindimugaya, C. (2012) Challenges and opportunities for sustainable groundwater 683 management in Africa. International Symposium, Enhancing Water Management Capacity in a 684 Changing World, Sao Paulo, June 2012.

685 Geng, X., Zhang, W., Stuecker, M.F., Liu, P., Jin, F.F., Tan, G. (2016) Decadal modulation of 686 the ENSO-East Asian winter monsoon relationship by the Atlantic Multidecadal Oscillation, 687 Climate Dynamics, 11, doi:10.1007/s00382-016-3465-0.

688 Giannini, A., Saravanan, R., Chang, P. (2003) Oceanic forcing of Sahel rainfall on interannual to 689 interdecadal time scales. Science, 302, pp. 1027-1030, doi:10.1126/science.1089357.

690 Giles, J. (2005) Solving Africa’s climate data problem. Nature, 435, pp. 862-863, doi: $691 \quad 10.1038 / 435862$ a.

692 Gleeson, T., Wada, Y., Bierkens, M.F.P., van Beek, L.P.H. (2012) Water balance of global 693 aquifers revealed by groundwater footprint, Nature, 488, pp. 197-200, doi:10.1038/nature11295.

694 Gning, A.A. (2015) Etude et modélisation hydrogéologique des interactions eaux de surface695 eaux souterraines dans un context d’agriculture irriguée dans le delta du fleuve Sénégal 696 (Hydrogeological study and modeling of surface water-groundwater interactions in an irrigated 697 agriculture context in the Senegal River delta), Ph.D. Thesis, Univ. De Liège, Belgium.

698 Gorelick, S.M., Zheng, C. (2015) Global change and the groundwater management challenge,

699 Water Resources Research, 51(5), pp. 3013-3051, doi:10.1002/2014WR016825.

700 Green, T., Taniguchi, M., Kooi, H., Gurdak, J.J., Allen, D.M., Hishcock, K.M., Treidel, H. and

701 Aureli, A. (2011) Beneath the surface of global change: Impacts of climate change on

702 groundwater. Journal of Hydrology, 405, pp. 532-560, doi:10.1016/j.jhydrol2011.05.002. 
703 Grinsted, A., Moore, J.C., Jevrejeva, S. (2004) Application of the cross wavelet transform and 704 wavelet coherence to geophysical time series, Nonlinear Processes in Geophysics, 11, pp. 561705 566, doi:10.5194/npg-11-561-2004.

706 Gurdak, J.J. (2017) Groundwater: Climate-induced pumping. Nature Geoscience, 10(71), 707 doi :10.1038/ngeo2885.

708 Gurdak, J.J., Hanson, R.T., McMahon, P.B., Bruce, B.W., McCray, J.E., Thyne, G.D. and 709 Reedy, R.C. (2007) Climate variability controls on unsaturated water and chemical movement, 710 High Plains aquifer, USA. Vadose Zone Journal, 6(2), pp. 533-547, doi:10.2136/vzj/2006.0087.

711 Hanson, R.T., Newhouse, M.W., Dettinger, M.D. (2004) A methodology to assess relations

712 between climatic variability and variations in hydrologic time series in the southwestern United

713 States. Journal of Hydrology, 287, pp. 252-269, doi:10.1016/j.jhydrol.2003.10.006.

714 Hassan, A., Jin, S.G. (2016) Water storage changes and balances in Africa observed by satellite 715 gravimetry and hydrologic models. Geodesy and Geodynamics, 7(1), pp. 39-49, 716 doi:10.1016/j.geog.2016.03.002.

717 Henry, C.M., Allen, D.M., Huang, J. (2011) Groundwater storage variability and annual recharge 718 using well-hydrograph and GRACE satellite data. Hydrogeology Journal, 19, 2, pp. 741-755, 719 doi: 10.1007/s10040-011-0724-3.

720 Holman, I.P., Rivas-Casado, M., Bloomfield, J.P., Gurdak, J.J. (2011) Identifying non-stationary 721 groundwater level response to North Atlantic ocean-atmosphere teleconnection patterns using 722 wavelet coherence. Hydrogeology Journal, 19, pp. 1269-1278, doi:10.1007/s10040-011-0755-9.

723 Houghton-Carr, H.A., Fry, M. J. (2006) The decline of hydrological data collection for 724 development of integrated water resource management tools in Southern Africa, Climate 
725 Variabilibilty and Change - Hydrological Impacts, Proceedings of the Fifth FRIEND World 726 Conference, IAHS Publ. 308.

727 Hurrell, J.W. (1995) Decadal trends in the north atlantic oscillation: regional temperatures and 728 precipitation. Science, 4, pp. 676-679, doi:10.1126/science.269.5224.676.

729 Hurrell, J.W., Kushnir, Y., Ottersen, G., Visbeck, M. (2003) An overview of the North Atlantic

730 Oscillation. In: Hurrell, J.W., Kushnir, Y., Ottersen, G., Visbeck, M. (eds) Geophysical

731 Monograph Series. American Geopphysical Union, Washington, D.C., pp. 1-35.

732 IGRAC (2017) Global Groundwater Monitoring Network - GGMN. https://ggmn.un-igrac.org.

733 Cited 6 June 2017.

734 IGRAC-UNESCO (2015) Transboundary Aquifers of the World [map]. Edition 2015. Scale 1 :

73550000 000. Delft, Netherlands : IGRAC, 2015.

736 Janicot, S., Ganiaux, G., Chauvin, F., de Coetlogon, G., Fontaine, B., Hall, N., Kiladis, G.,

737 Lafore, J.P., Lavaysse, C., Lavender, S.L., Leroux, S., Marteau, R., Mounier, F., Philippon, N.,

738 Roehrig, R., Sultan, B. and Taylor, C.M. (2011) Intraseasonal variability of the West African

739 monsoon, Atmospheric Science Letters, 12(1), pp. 58-66, doi: 10.1002/asl.280.

740 Jung, M., Reichstein, M., Ciais, P., Seneviratne, S.I., Sheffield, J., Goulden, M.L., Bonan, G.,

741 Cascatti, A., Chen, J., de Jeu, R., Dolman, A.J., Eugster, W., Gerten, D., Gianelle, D., Gobron,

742 N., Heinke, J., Kimball, J., Law, B.E., Montagnani, L., Mu, Q., Mueller, B., Oleson, K., Papale,

743 D., Richardson, A.D., Roupsard, O., Running, S., Tomelleri, E., Viovy, N., Weber, U., Williams,

744 C., Wood, E., Zaehle, S. and Zhang, K. (2010) Recent decline in the global land

745 evapotranspiration trend due to limited moisture supply. Nature, 467, pp. 951-954,

746 doi:10.1038/nature09396. 
747 Knudsen, M.F., Seidenkrantz, M-S., Jacobsen, B.H. (2011) Tracking the Atlantic Multidecadal

748 through the last 8,000 years. Nature Communications, 2, p. 178, doi:10.1038/ncomms1186.

749 Konikow, L.F. (2015) Long-Term Gorundwater Depletion in the United States. Groundwater,

750 53(1), pp. 2-9, doi:10.1111/gwat.12306.

751 Kuss, A.J.M., Gurdak, J.J. (2014) Groundwater level response in U.S. principal aquifers to

752 ENSO, NAO, PDO, and AMO. Journal of Hydrology, 519, pp. 1939-1952,

753 doi:10.1016/j.jhydrol.2014.09.069.

754 Labat, D. (2005). Recent advances in wavelet analyses: Part 1. A review of concepts. Journal of 755 Hydrology, 314, pp. 275-288, doi:10.1016/j.jhydrol.2005.04.003.

756 Labat, D. (2008). Wavelet analysis of the annual discharge records of the world's largest rivers.

757 Advances in Water Resources, 31(1), pp. 109-117, doi:10.1016/j.advwatres.2007.07.004.

758 Labat, D., Ababou, R., Mangin, A (2000) Rainfall-runoff relations for karstic springs.Part II:

759 Continuous wavelet and discrete orthogonal multiresolution analyses. Journal of Hydrology, 760 238, pp. 149-178, doi:10.1016/S0022-1694(00)00322-X.

761 Lapworth, D.J., McDonald, A.M., Tijani, M.N., Darling, W.G., Gooddy, W.G., Bonsor, H.C., 762 Araguas-Araguas, L.J. (2013) Residence times of shallow groundwater in West Africa:

763 implications for hydrogeology and resilience to future changes in climate. Hydrogeology

764 Journal, 21, 3, pp. 673-686, doi: 10.1007/s10040-012-0925-4.

765 Li, J., Xie, S.P., Cook, E.R.,Morales, M.S., Christie, D.A., Nathaniel, C.J., Chen, F., D’Arrigo, 766 R., Fowler, A.M., and Gou, X. and Fang, K. (2013) El Niño modulations over the past seven 767 centuries. Nature Climate Change, 3, pp. 822-826, doi :10.1038/nclimate1936. 
769 evapotranspiration and runoff over the drainage basins of the Gulf of Mexico during the 1901-

770 2008, Water Resources Research, 49, 4, doi: 10.1002/wrcr.20180.

771 Long, D., Longuevergne, L., Scanlon, B.R. (2015) Global analysis of approaches for deriving

772 total water storage changes from GRACE satellites. Water Resources Research, 51 (4), pp.2574-

773 2594, doi:10.1002/ 2014WR016853.

774 Longuevergne, L., Scanlon, B.R., Wilson, C.R. (2010) GRACE hydrological estimates for small

775 basins: Evaluating processing approaches on the High Plains Aquifer, USA, Water Resources

776 Research, 46, doi:10.1029/2009WR008564.

777 López-Moreno, J.I., Vicente-Serrano, S.M., Morán-Tejeda, E., Lorenzo-Lacruz, J., Kenawy, A.

778 and Beniston, M. (2011) Effects of the North Atlantic Oscillation (NAO) on combined

779 temperature and precipitation Winter modes in the Mediterranean mountains: observed

780 relationships and projects for the $21^{\text {st }}$ century. Global and Planetary Change, 77, pp. 62-76, doi:

$781 \quad$ 10.1016/j.gloplacha.2011.03.003.

782 Lutz, A., Minyila, S., Saga, B. Diarra, S., Apambire, B. and Thomas, J. (2015) Fluctuation of

783 Groundwater Levels and Recharge Patterns in Northern Ghana. Climate, 3, pp. 1-15, doi:

784 10.3390/cli3010001.

785 MacDonald, A.M., Bonsor, H.C., Dochartaigh, B.E.O. and Taylor, R.G. (2012) Quantitative

786 maps of groundwater resources in Africa. Environmental Research Letters, 7(2), doi:

$787 \quad 10.1088 / 1748-9326 / 7 / 2 / 024009$.

788 Maidment, R.I., Allan, R.P., Black, E. (2015) Recent observed and simulated changes in

789 precipitation over Afica. Geophysical Research Letters, 42(19), pp. 8155-8164, doi:

$790 \quad 10.1002 / 2015 G L 065765$. 
791 Malherbe, J., Dieppois, B., Maluleke, P., van Staden, M. and Pillay, D.L. (2016) South African 792 droughts and decadal variability. Natural Hazards, 80(1), pp. 657-681, doi: 0.1007/s11069-015793 1989-y.

794 Manatsa, D., Matarira, C., Mukwada, G. (2011) Relative impacts of ENSO and Indian Ocean 795 dipole/zonal mode on east SADC rainfall. International Journal of Climatology, 31, pp. 558796 577, doi:10.1002/joc.2086.

797 Massuel, S. and Riaux, J. (2017) Groundwater overexploitation: why is the red flag waved? Case 798 study on the Kairouan aquifer (central Tunisia). Hydrogeology Journal, 25, 6, pp. 1607-1620, 799 doi: 10.1007/s10040-017-1568-2.

800 Marchant, R., Mumbi, C., Behera, S., Yamagata, T. (2006) The Indian Ocean dipole - the 801 unsung driver of climatic variability in East Africa. African Journal of Ecology, 45, 1, doi: 802 10.1111/j.1365-2028.2006.00707.x.

803 Masih, I., Maskey, S., Mussa, F.E.F. and Trambauer, P. (2014) A review of droughts on the 804 African continent: a geospatial and long-term perspective. Hydrology and Earth System 805 Sciences, 18, pp. 3635-3649, doi: 10.5194/hess-18-3635-2014.

806 Maurice L., Taylor, R.G., Tindimugaya, C., MacDonald, A. M., Johnson, P., Kaponda, A., Owor 807 M., Sanga, H., Bonsor, H.C., Darling, W.G., and Gooddy, D. (2018) Characteristics of high808 intensity groundwater abstractions from weathered crystalline bedrock aquifers in East Africa. 809 Hydrogeology Journal, THIS ISSUE

810 McCarthy, G.D., Haigh, I.D., Hirschi, J.J.M., Grist, J.P. and Smeed, D.A. (2015) Ocean impact 811 on decadal Atlantic climate variability revealed by sea-level observations. Nature, 521, pp. 508812 510, doi : 10.1038/nature14491. 
813 Messekher, I., Chabour, N., Menani, M.R. (2012) Remontée de la nappe phréatique du Souf :

814 consequences et solutions envisagées (Rise of the Souf water table: consequences and solutions

815 envisaged). Annals of the University of Bucarest.

816 http://annalsreview.geo.unibuc.ro/2012/Ishak.pdf. Cited 6 June 2017.

817 Meyer, C. (2016) Développement d'outil pour la cartographie de l'indicateur 6.5.2 des ODD sur

818 la coopération internationale dans le domaine de l'eau (Development of a tool for mapping SDG

819 indicator 6.5.2 on transboundary water cooperation). MSc. Thesis, Univ. Paris 10, France.

820 Mohino, E., Rodriguez-Fonseca, B., Mechoso, C.R., Gervois, S., Ruti, P. and Chauvin, F. (2011)

821 Impacts of the Tropical Pacific/Indian Oceans on the Seasonal Cycle of the West African

822 Monsoon. Journal of Climate, 24, pp. 3878-3891, doi :10.1175/2011JCLI3988.1.

823 Mueller, B. Seneviratne, Jimenez, C., Corti, T., Hirschi, M., Balsamo, G., Ciais, P., Dirmeyer, P., 824 Fisher, J.B., Guo, Z., Maignan, F., McCabe, Reichle, R., Reichstein, M., Rodell, M., Sheffield,

825 J., Teuling, A.J. Teuling, Wang, K., Wood, E.F. and Zhang, Y. (2011) Evaluation of global

826 observations-based evapotranspiration datasets and IPCC AR4 simulations, Geophysical

827 Research Letters, 38, 6, doi:10.1029/2010GL046230.

828 Nazoumou, Y., Favreau, G., Babaye, M.S.A., Goni, I.B. (2015) Climate variability, land use and 829 groundwater storage in a large sedimentary aquifer of the Sahel region (Iullemeden Basin,

830 Niger). Proceedings of the $42^{\text {nd }}$ IAH Congress, Rome, Italy.

831 Ndehedehe, C.L., Awange, J.L., Kuhn, M. Agutu, N.O. and Fukuda, Y. (2017) Climate

832 teleconnections influence on West Africa's terrestrial water storage. Hydrological Processes, pp.

833 1-19, doi :10.1002/hyp.11237.

834 Ngounou-Ngatcha, B.N., Favreau, G., Le Coz, M., Nazoumou, Y., Boucher, M. and Goni, I.

835 (2015) Long term changes in groundwater storage in the Lake Chad Basin, central Africa, as a 
836 function of drought periods and lake fluctuations. Proceedings of the $42^{\text {nd }}$ IAH Congress, Rome, 837 Italy.

838 NOAA (2017) Climate Indices: Monthly Atmospheric and Ocean Time Series. Earth System

839 Research Laboratory, Physical Sciences Division.

840 https://www.esrl.noaa.gov/psd/data/climateindices/list/. Cited 6 June 2017.

841 Nicholson, S.E., Selato, J.C. (2000) The influence of La Nina on African rainfall. International

842 Journal of Climatology, 20, pp. 1761-1776, doi: 10.1002/1097-0088.

843 Okonkwo, C., Demoz, B., Sakai, R. Ichoku, C., Anarado, C. and Adegoke, J. (2015) Combined

844 effect of El Niño southern oscillation and Atlantic multidecadal oscillation on Lake Chad level

845 variability. Cogent Geoscience, 1, pp. 1-19, doi:10.1080/23312041.2015.1117829.

846 Onyutha, C. and Willems, P. (2017) Space-time variability of extreme rainfall in the River Nile

847 basin. International Journal of Climatology, 34, 14, pp. 4915-4924, doi: 10.1002/joc.5132

848 OSS (2003) Système Aquifère du Sahara Septentrional - Gestion commune d'un bassin

849 transfrontière, Rapport de synthèse, $1^{\text {ère }}$ edition (North-Western Sahara Aquifer System - Joint

850 Management of a Transboundary Basin, Summary Report, 1st edition). ISBN:9973-856-03-1.

851 Owusu, K., Waylen, P.R., Qui, Y. (2008) Changing rainfall inputs in the Volta basin:

852 implications for water sharing in Ghana. GeoJournal, 71(4), pp. 201-210, doi: 10.1007/s10708-

853 008-9156-6.

854 Palmer, T.N., Anderson, D.L.T. (1994) The prospects for seasonal forecasting-A review paper.

855 Quarterly Journal of the Royal Meteorological Society, 120, pp. 755-793,

856 doi:10.1002/qj.49712051802. 
857 Peings, Y., Magnusdottir, G. (2014) Forcing of the wintertime atmospheric circulation by the

858 multidecadal fluctuations of the North Atlantic ocean. Environmental Research Letters, 9(3),

859 doi : 10.1088/1748-9326/9/3/034018.

860 Philippon, N., Rouault, M., Richard, Y. and Favre, A. (2012) The influence of ENSO on winter

861 rainfall in South Africa. International Journal of Climatology, 32, pp. 2333-2347,

862 doi:10.1002/joc.3403.

863 Prudhomme, C., Giuntoli, I., Robinson, E.L., Clark, D.B., Arnell, N.W., Dankers, R., Fekete,

864 B.M., Franssen, W., Gerten, D., Gosling, S.N., Hagemman, S., Hannah, D.M., Kim, H., Masaki,

865 Y., Satoh, Y., Stacke, T., Wada, Y. and Wisser, D. (2014) Hydrological droughts in the $21^{\text {st }}$

866 century, hotspots and uncertainties from a global multimodel ensemble experiment. Proceedings

867 of the National Academy of Sciences, 111(4), pp. 3262-3267, doi: 10.1073/pnas.1222473110.

868 Ramilien, G., Frappart, F., Seoane, L. (2014) Application of the Regional Water Mass Variations

869 from GRACE Satellite Gravimetry to Large-Scale Water Management in Africa. Remote

$870 \quad$ Sensing, 6, pp. 7379-7405, doi:10.3390/rs6087379.

871 Rateb, A., Kuo, C.Y., Imani, M. Tseng, K.H., Lan, W.H., Ching, K.E. and Tseng, T.P. (2017)

872 Terrestrial Water Storage in African Hydrological Regimes Derived from GRACE Mission Data:

873 Intercomparison of Spherical Harmonics, Mass Concentration, and Scalar Slepian Methods.

874 Sensors, 17(3), doi : 10.3390/s17030566.

875 Richard ,Y., Fauchereau, N., Poccard, I., Rouault, M. and Trzaska, S. (2001) 20 ${ }^{\text {th }}$ Century

876 droughts in southern Africa: spatial and temporal variability, teleconnections with oceanic and

877 atmospheric conditions. International Journal of Climatology, 21, pp. 873-885,

878 doi:10.1002/joc.656. 
879 Richey, A.S., Thomas, B.F., Lo, M.H., Reager, J.T., Famiglietti, J.S., Voss, K., Swenson, S. and

880 Rodell, M. (2015) Quantifying renewable groundwater stress with GRACE, Water Resources

881 Research, 51, pp. 5217-5238, doi:10.1002/2015WR017349.

882 Robins, N.S., Davies, J., Farr, J.L., Calow, R.C. (2006) The changing role of hydrogeology in 883 semi-arid southern and eastern Africa, Hydrogeology Journal, 14, 8, pp. 1483-1492,

884 doi:10.1007/s10040-006-0056-X.

885 Russo, T.A., Lall, U. (2017) Depletion and response of deep groundwater to climate-induced 886 pumping variability. Nature Geoscience, 10, pp. 105-108, doi : 10.1038/ngeo2883.

887 Scanlon, B.R., Keese, K.E., Flint, A.L., Flint, L.E., Gaye, C.B., Edmunds, W.M. and Simmers, I. 888 (2006) Global synthesis of groundwater recharge in semiarid and arid regions. Hydrological 889 Processes, 20, pp. 3335-3370, doi:10.1002/hyp.6335.

890 Scanlon, B.R., Zhang, Z., Save, H., Wiese, D.N., Landerer, F.W., Long, D., Longuevergne, L. 891 and Chen, J. (2016) Global evaluation of new GRACE mascon products for hydrologic 892 applications. Water Resources Research, 56, 12, pp. 9412-9429, doi: 10.1002/2016WR019494. 893 Shanahan, T.M., Overpeck, J.T., Anchukaitis, K.J., Beck, J.W., Cole, J.E., Dettman, D.L., Peck, 894 J.A., Scholz, C.A. and King, J.W. (2009), Atlantic forcing of persistent drought in West Africa, 895 Science, 324(5925), pp. 377-380, doi:10.1126/science.1166352.

896 Siam, M.S., Eltahir, E.A.B. (2017) Climate change enhances interannual variability of the Nile 897 river flow. Nature Climate Change, 7, pp. 350-354, doi :10.1038/nclimate3273.

898 Siebert, S., Burke, J., Faures, J.M., Frenken, K., Hoogeveen, J., Doll, P. and Portmann, F.T. 899 (2010) Groundwater use for irrigation - a global inventory. Hydrology and Earth System 900 Sciences, 14, pp. 1863-1880, doi:10.5194/hess-14-1863-2010. 
901 Sun, A. Y., Scanlon, B.R., Agha Kouchal, A., Zhang, Z. (2017) Using GRACE satellite

902 gravimetry for assessing large-scale hydrological extremes, Remote Sensing, 9, 12, pp. 1287-

903 1312, doi: 10.3390/rs9121287.

904 Sun, Q., Miao, C., Duan, Q., Ashouri, H., Sorooshian, S., Hsu, K.L. (2018) A review of global

905 precipitation data Ssets: Data Sources, estimation, and intercomparisons, Reviews of

906 Geophysics, 56, doi: 10.1002/2017RG000574.

907 Swenson, S., Wahr, J. (2006) Post-processing removal of correlated errors in GRACE

908 data, Geophysical Research Letters, 33, doi:10.1029/2005GL025285.

909 Taylor, R.G., Koussis, A.D., Tindimugaya, C. (2009) Groundwater and climate in Africa - a

910 review. Hydrological Sciences Journal, 54, pp. 655-664, doi:10.1623/hysj.54.4.655.

911 Taylor, R.G., Scanlon, B., Doll, P., Rodell, M., van Beek, R., Wada, Y., Longuevergne, L.,

912 Leblanc, M., Famiglietti, J.S., Edmunds, M., Konikow, L., Green, T.R., Chen, J., Taniguchi, M.,

913 Bierkens, M.F.P., MacDonald, A., Fan, Y., Maxwell, R.M., Yechieli, Y., Gurdak, J.J., Allen,

914 D.M., Shamsudduha, M., Hiscock, K., Yeh, P.J.F., Holman, I. and Treidel, H. (2013) Ground

915 water and climate change, Nature Climate Change, 3, pp. 322-329, doi:10.1038/nclimate1744.

916 Taylor, R.G., Todd, M.C., Kongola, L., Maurice, L., Nahozya, E., Sanga, H. and MacDonald,

917 A.M. (2013) Evidence of the dependence of groundwater resources on extreme rainfall in East

918 Africa. Nature Climate Change, 3, pp. 374-378, doi:10.1038/nclimate1731.

919 Timmermann, A., Okumura, Y., An, S.I., Clement, A., Dong, B., Guilyardi, E., Hu, A.,

920 Jungclaus, J.H., Renold, M., Stocker, T.F., Stouffer, R.J., Sutton, R., Xie, S.P. and Yin, J. (2007),

921 The influence of a weakening of the Atlantic meridional overturning circulation on ENSO,

922 Journal of Climate, 20(19), pp. 4899-4919, doi:10.1175/JCLI4283.1. 
923 Torrence, C., Compo, G.P. (1998) A practical guide to wavelet analysis. Bulletin of the American

924 Meteorological Society, 79(1), pp. 61-78.

925 Treidel, H., Martin-Bordes, J.L., Gurdak, J.J. (eds) (2012) Climate change effects on

926 groundwater resources: A global synthesis of findings and recommendations, International

927 Association of Hydrogeologists (IAH) - International Contribution to Hydrogeology, Taylor \&

928 Francis publishing, 414 p., ISBN 978-0415689366.

929 Trenberth, K.E., Dai, A., van der Schrier, G., Jones, P.D., Barichivich, J., Briffa, K.R. and

930 Sheffield, J. (2014) Global warming and changes in drought. Nature Climate Change, 4, pp. 17-

$931 \quad 22$, doi:10.1038/nclimate2067.

932 Tuinhof, A., Foster, S., van Steenbergen, F., Talbi, A. and Wishart, M. (2011) Appropriate

933 groundwater management policy for Sub-Saharan Africa in face of demographic pressure and

934 climatic variability. GW MATE strategic overview series, 5, Washington, DC: World Bank.

935 UNESCO (2009) IWRM implementation in basins, sub-basins and aquifers: state of the art

936 review. World Water Assessment Programme, Side publications series, Insights, ISBN 978-92-3-

$937 \quad 104105-1$.

938 UNESCO (2016) Stampriet Transboundary Aquifer System assessment, Governance of

939 Groundwater Resources in Transboundary Aquifers,

940 http://unesdoc.unesco.org/images/0024/002452/245265e.pdf. Cited 6 June 2017

941 UNESCO and UNECE (2017) Step-by-step methodology for monitoring transboundary

942 cooperation, Integrated Monitoring Guide for SDG 6. http://www.unwater.org/publications/step-

943 step-methodology-monitoring-transboundary-cooperation-6-5-2/. Cited 6 June 2017

944 Van der Gun, J. (2012) Groundwater and global change: trends, opportunities and challenges.

945 World Water Assessment Programme, Side publication series, ISBN 978-92-3-001049-2. 
Vasollo, S. (2017) Personal communication.

947 Vorosmarty, C.J., Douglas, E.M., Green, P.A. and Revenga, C. (2005) Geospatial indicators of

948 emerging water stress: an application to Africa. Ambio, 34(3), pp. 230-236.

949 Wada, Y., Bierkens, M.F.P. (2014) Sustainability of global water use: past reconstruction and

950 future projections. Environmental Research Letters, 9, doi: 10.1088/1748-9326/9/10/104003.

951 Wada, Y., van Beek, L.P.H., van Kempen, C.M. (2010) Global depletion of groundwater

952 resources. Geophysical Research Letters, 37(20), doi:10.1029/2010GL044571.

953 Wang, S.., Huang, J., He, Y. Guan, Y. (2014) Combined effects of the Pacific Decadal

954 Oscillation and El Niño-Southern Oscillation on Global Land Dry-Wet Changes. Scientific

955 Reports, 4, doi:10.1038/srep06651.

956 Wani S.P., Sreedevi T.K., Rockström J. et al. (2009) Rain-fed agriculture - Past trend and future

957 prospects. In Wani S.P., Rockström J., Oweis, T. (eds) Rain-fed agriculture: Unlocking the

958 Potential. Comprehensive Assessment of Water Management in Agriculture Series. CAB

959 International, Wallingford, UK, pp. 1-35.

960 Washington, R., James, R., Pearce, H. Pokam, W.M. and Moufouma-Okia, W. (2013) Congo

961 Basin rainfall climatology: Can we believe the climate models? Philosophical Transactions of

962 the Royal Society, London, Ser. B, 368(1625), doi:10.1098/rstb.2012.0296.

964 WMO (1996) The adequacy of hydrological networks: a global assessment. Tech. Document no.

965 740. WMO, Geneva, Switzerland.

966 Zhang, Y., Wallace J.M., Battisti, D.S. (1997) ENSO-like interdecadal variability. Journal of

967 Climate, 10, pp. 1004-1020, doi:10.1175/1520-0442. 
968 Zhang, W., Jin, F.F., Zhao, J.X. and Li, J. (2012) On the bias in simulated ENSO SSTA

969 meridional widths of CMIP3 models, Journal of Climate, doi:10.1175/JCLI-D-12-00347.1.

970 Zhou, L., Tian, Y., Myneni, R.B., Ciais, P., Saatch, S., Liu, Y.Y., Piao, S., Chen, H., Vermote,

971 E.F., Song, C. and Hwang, T. (2014) Widespread decline of Congo rainforest greenness in the

972 past decade, Nature, 509, pp. 86-90, doi: 10.1038/nature13265.

973 Zouari, K. (2015) Progress in the implementation of the project RAF 7011 on the assessment of

974 shared aquifer systems in the Sahel region. International Symposium on Isotope Hydrology:

975 Revisiting Foundations and Exploring Frontiers, 11-15 May 2015, IAEA Headquarters, Vienna, 976 Austria.

977

978 Acknowledgements:

979 This study is a contribution to UNESCO International Hydrological Programme (IHP) Groundwater

980 Resources Assessment under the Pressures of Humanity and Climate Change (GRAPHIC) project.

981 The authors are grateful to the support provided by Richard Taylor (UCL), Aurélien Dumont and

982 Marina Rubio (UNESCO-IHP - Groundwater Systems and Settlements Section) on the review of this 983 paper.

984

985 
Appendix: Acronyms and abbreviations

987

\begin{tabular}{|l|l|}
\hline TWS & Total water storage \\
\hline$\Delta$ GWS & Groundwater storage changes \\
\hline$\Delta \mathrm{GWS}_{\text {OBSERVED }}$ & Observed groundwater storage changes \\
\hline$\Delta \mathrm{TWS}$ & Total water storage changes \\
\hline$\Delta \mathrm{TWS}_{\text {GRACE }}$ & GRACE-based changes in total water storage \\
\hline$\Delta \mathrm{TWS}_{\text {MODEL }}$ & Simulated changes in total water storage \\
\hline AMO & Atlantic Multidecadal Oscillation \\
\hline CWT & Continuous wavelet transform \\
\hline ENSO & El Niño Southern Oscillation \\
\hline GRACE & Gravity Recovery And Climate Experiment \\
\hline IOD & Indian Ocean Dipole \\
\hline ITTAS & Iullemmeden, Taoudeni/Tanezrouft Aquifer System \\
\hline IWRM & Integrated Water Resources Management \\
\hline MAR & Managed Aquifer Recharge \\
\hline MEI & Multivariate ENSO Index \\
\hline NAO & North Atlantic Oscillation \\
\hline NSAS & Nubian Sandstone Aquifer System \\
\hline NWSAS & North-Western Sahara Aquifer System \\
\hline PDO & Pacific Decadal Oscillation \\
\hline STAS & Stampriet Transboundary Aquifer System \\
\hline WTC & Wavelet coherence \\
\hline XWT & Cross wavelet transform \\
\hline
\end{tabular}


Table 1 - Basic hydrogeological, socio-economic and governance overview of the studied aquifers

\begin{tabular}{|c|c|c|c|c|c|c|c|}
\hline $\begin{array}{l}\text { Aquifer } \\
\text { No. } \\
\text { (Fig. 1) }\end{array}$ & Aquifer & Zone & $\begin{array}{l}\text { Population } \\
\text { (approx. } \\
\text { no. of } \\
\text { inhabitants) }\end{array}$ & $\begin{array}{l}\text { Approx. } \\
\text { area } \\
\left(\mathbf{k m}^{2}\right)\end{array}$ & $\begin{array}{l}\text { Rainfall } \\
\text { (mm/year) }\end{array}$ & Aquifer type & $\begin{array}{l}\text { Institutional } \\
\text { arrangement }\end{array}$ \\
\hline 1 & $\begin{array}{l}\text { North-Western } \\
\text { Sahara } \\
\text { Aquifer } \\
\text { System } \\
\text { (NWSAS) } \\
\end{array}$ & Northern Africa & $4,000,000$ & $1,300,000$ & $10-300$ & $\begin{array}{l}\text { Sand, sandstone, } \\
\text { sandy clay, } \\
\text { calcareous, dolomite }\end{array}$ & $\begin{array}{l}\text { Observatory of } \\
\text { the Sahara and } \\
\text { the Sahel (OSS) }\end{array}$ \\
\hline 2 & $\begin{array}{l}\text { Nubian } \\
\text { Sandstone } \\
\text { Aquifer } \\
\text { System } \\
\text { (NSAS) } \\
\end{array}$ & Northern Africa & $67,000,000$ & $2,800,000$ & $1-550$ & $\begin{array}{l}\text { Nubian and Post- } \\
\text { Nubian }\end{array}$ & Joint Authority \\
\hline 3 & $\begin{array}{l}\text { Senegalo- } \\
\text { Mauritanian } \\
\text { Basin }\end{array}$ & Sahel & $12,000,000$ & 330,000 & $20-1,850$ & $\begin{array}{l}\text { Quaternary - } \\
\text { Maestrichtien }\end{array}$ & $\begin{array}{l}\text { Senegal River } \\
\text { Basin } \\
\text { Development } \\
\text { Authority } \\
\text { (potential) } \\
\end{array}$ \\
\hline 4 & $\begin{array}{l}\text { Irhazer- } \\
\text { Iulluemmeden } \\
\text { Basin }\end{array}$ & Sahara-Sahel & $13,000,000$ & 580,000 & $80-900$ & $\begin{array}{l}\text { Sedimentary deposit } \\
\text { including Terminal } \\
\text { Continental and } \\
\text { Intercalary } \\
\text { Continental } \\
\text { (Cretaceous - } \\
\text { Tertiary) } \\
\end{array}$ & $\begin{array}{l}\text { Consultation } \\
\text { mechanism to } \\
\text { be } \\
\text { operationalized }\end{array}$ \\
\hline 5 & $\begin{array}{l}\text { Lake Chad } \\
\text { Basin }\end{array}$ & Sahara-Sahel & $22,000,000$ & $2,300,000$ & $40-1,400$ & $\begin{array}{l}\text { Sedimentary: Upper } \\
\text { Quaternary, lower } \\
\text { Pliocene and } \\
\text { Continental } \\
\text { Terminal (Tertiary) }\end{array}$ & $\begin{array}{l}\text { Lake Chad } \\
\text { Basin } \\
\text { Commission } \\
\text { (potential) }\end{array}$ \\
\hline 6 & Volta Basin & $\begin{array}{l}\text { Tropical/Equatorial } \\
\text { Africa }\end{array}$ & $14,000,000$ & 145,000 & $500-1,100$ & Sedimentary rocks & $\begin{array}{l}\text { Volta Basin } \\
\text { Authority } \\
\text { (potential) }\end{array}$ \\
\hline 7 & $\begin{array}{l}\text { Karoo- } \\
\text { Carbonate }\end{array}$ & Equatorial Africa & $10,000,000$ & 600,000 & $\begin{array}{l}1,000- \\
1,800\end{array}$ & Limestone/sandstone & $\begin{array}{l}\text { International } \\
\text { Commission of } \\
\text { the Congo- } \\
\text { Oubangui- } \\
\text { Sangha } \\
\text { Basin (potential) }\end{array}$ \\
\hline 8 & $\begin{array}{l}\text { Stampriet } \\
\text { Transboundary } \\
\text { Aquifer } \\
\text { System } \\
\end{array}$ & Southern Africa & 50,000 & 90,000 & $200-350$ & $\begin{array}{l}\text { Kalahari group } \\
\text { aquifers and Karoo } \\
\text { supergroup aquifers }\end{array}$ & $\begin{array}{l}\text { Orange-Senqu } \\
\text { River } \\
\text { Commission }\end{array}$ \\
\hline 9 & $\begin{array}{l}\text { Karoo } \\
\text { Sedimentary }\end{array}$ & Southern Africa & $6,000,000$ & 170,000 & $350-1,200$ & $\begin{array}{l}\text { Consolidated } \\
\text { sedimentary rocks }\end{array}$ & $\begin{array}{l}\text { Orange-Senqu } \\
\text { River } \\
\text { Commission } \\
\text { (potential) }\end{array}$ \\
\hline
\end{tabular}


Table 2 - Ground-based measurements in the studied aquifers

\begin{tabular}{|c|c|c|c|c|}
\hline $\begin{array}{l}\text { Aquifer } \\
\text { No. }\end{array}$ & Aquifer & $\begin{array}{l}\text { Groundwater- } \\
\text { level time frame }\end{array}$ & Well/Borehole depth & Source \\
\hline 1 & $\begin{array}{l}\text { North-Western Sahara Aquifer } \\
\text { System (NWSAS) }\end{array}$ & $1982-2011$ & $\begin{array}{l}\text { Shallow piezometer } \\
\text { (located near the } \\
\text { boundaries of the } \\
\text { aquifer) }\end{array}$ & $\begin{array}{l}\text { Massuel and Riaux, } \\
2017\end{array}$ \\
\hline 2 & $\begin{array}{l}\text { Nubian Sandstone Aquifer System } \\
\text { (NSAS) }\end{array}$ & 1998-2004 & $\begin{array}{l}\text { Shallow piezometer } \\
\text { (vicinity of Lake } \\
\text { Nasser) }\end{array}$ & El Shazli, 2018 \\
\hline 3 & Senegalo-Mauritanian Basin & $1997-2002$ & $\begin{array}{l}\text { Shallow piezometer } \\
\text { (vicinity of Senegal } \\
\text { River) }\end{array}$ & Gning et al., 2015 \\
\hline 4 & Irhazer-Iullemmeden Basin & 1991-2015 & $\begin{array}{l}<75 \mathrm{~m} \\
(<75 \mathrm{~km} \text { from the } \\
\text { Niger River })\end{array}$ & $\begin{array}{l}\text { Updated from } \\
\text { Favreau et al., } 2009\end{array}$ \\
\hline 5 & Lake Chad Basin & $2006-2011$ & $\begin{array}{l}\text { 85m } \\
\text { (Maiduguri - vicinity } \\
\text { of Lake Chad) }\end{array}$ & Vasollo, 2017 \\
\hline 6 & Volta Basin & $2006-2011$ & Shallow piezometer & Lutz et al., 2015 \\
\hline 7 & Karoo-Carbonate & N/A & N/A & N/A \\
\hline 8 & $\begin{array}{l}\text { Stampriet Transboundary Aquifer } \\
\text { System }\end{array}$ & 1986-2008 & $\begin{array}{l}\text { Shallow piezometer } \\
(<50 \mathrm{~m})\end{array}$ & UNESCO, 2016 \\
\hline 9 & Karoo Sedimentary & 1994-1999 & $\begin{array}{l}\text { Shallow piezometer } \\
(<10 \mathrm{~m})\end{array}$ & IGRAC, 2017 \\
\hline
\end{tabular}

N/A : not applicable 
FIGURE CAPTIONS:

Figure 1 - Location of the studied aquifers in Africa

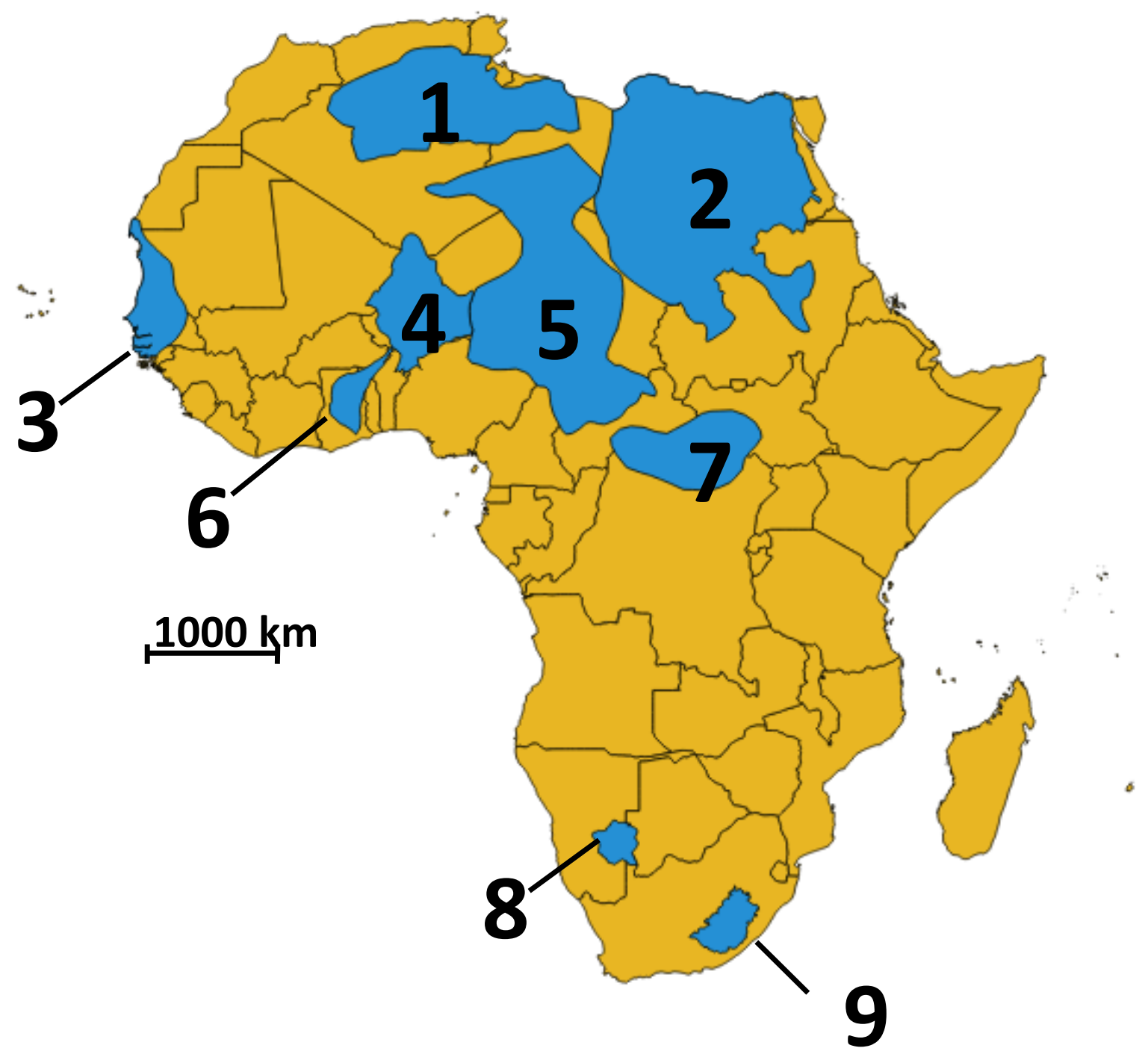


Figure 2 - Groundwater level fluctuation in the studied aquifers

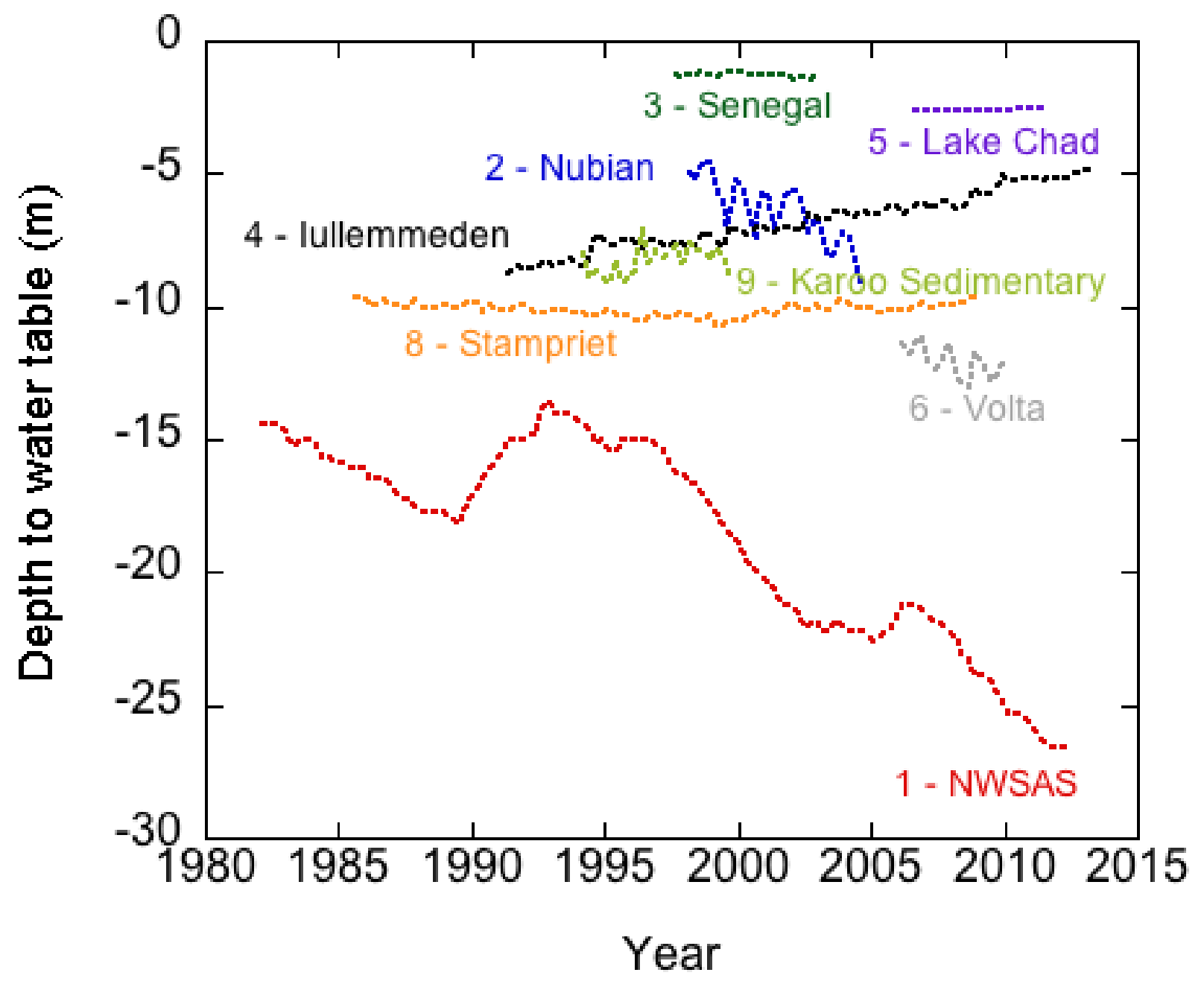




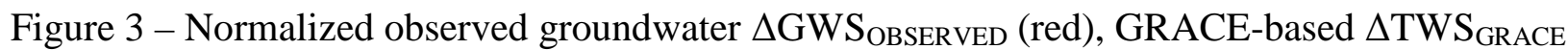
(blue) and model-based total water storage variability $\Delta \mathrm{TWS}_{\mathrm{MODEL}}$ (green) in the studied
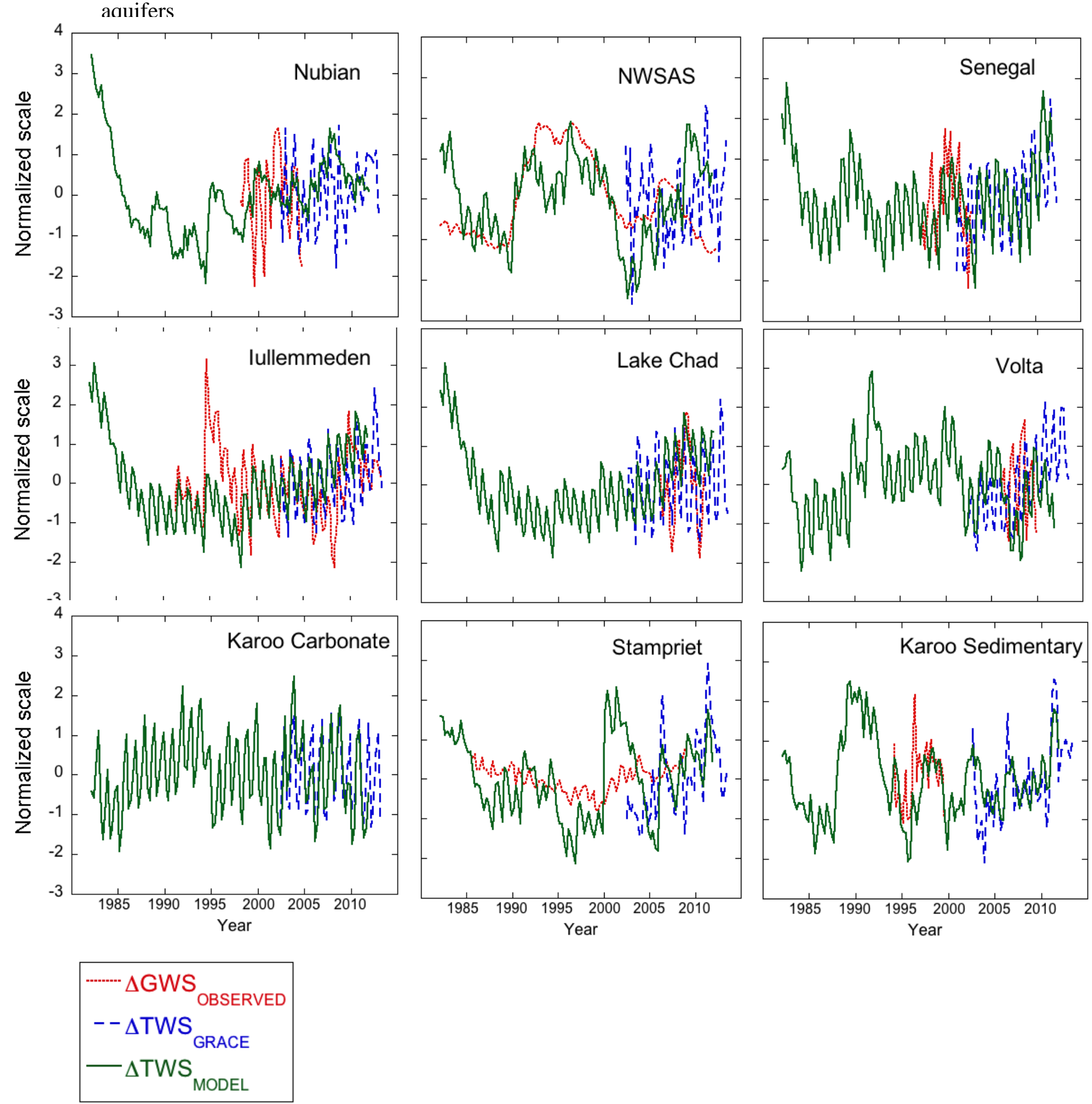
Figure 4 - Wavelet coherence (WTC) plots in the studied aquifers: a Northern Africa and Sahara-Sahel, and b Tropical/Equatorial Africa and Southern Africa

(Note: $\mathrm{x}$-axis is date (year) and y-axis is period in years. Correlation coefficients vary from 0 (dark blue) to 1(light yellow))

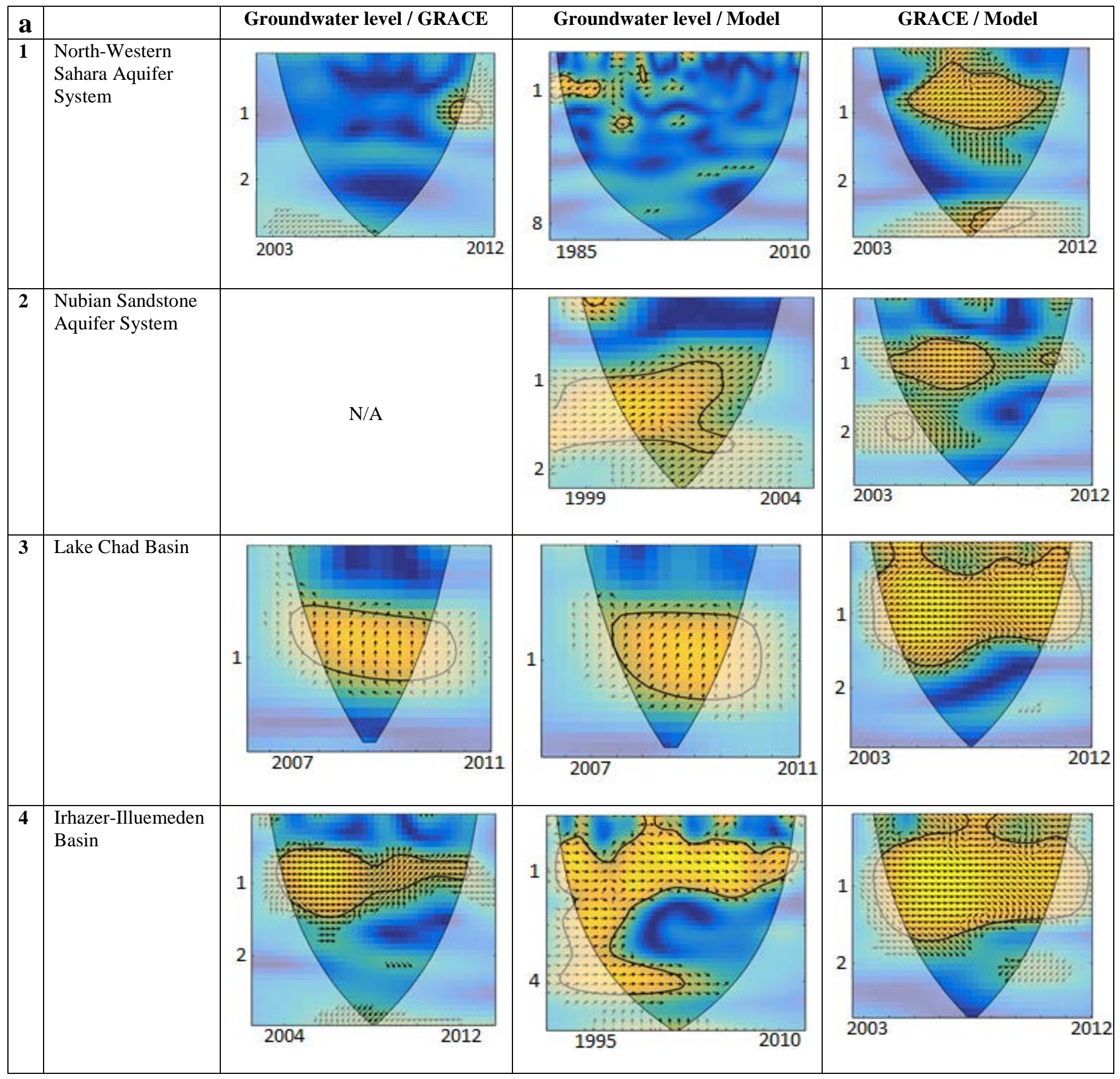




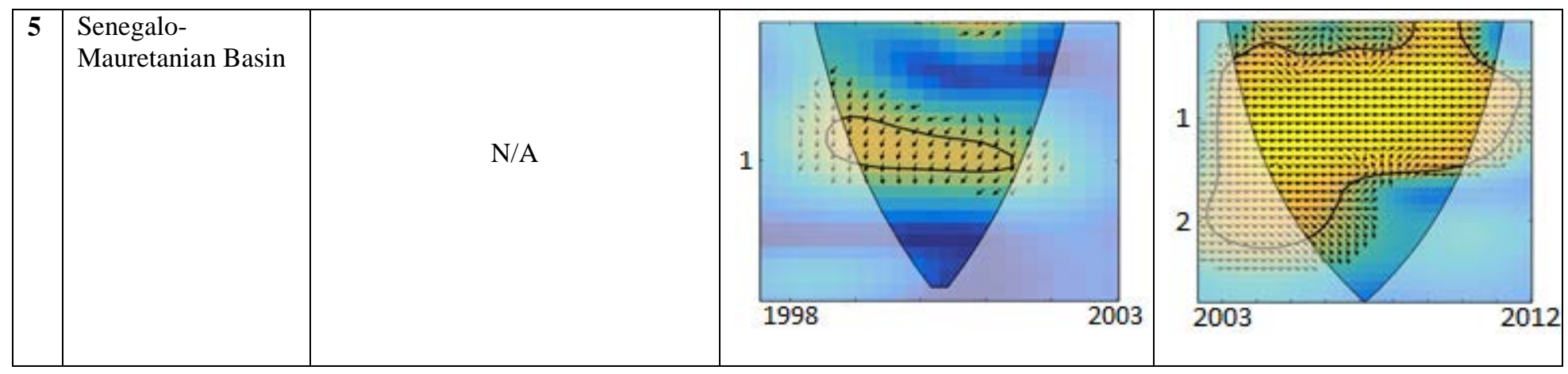

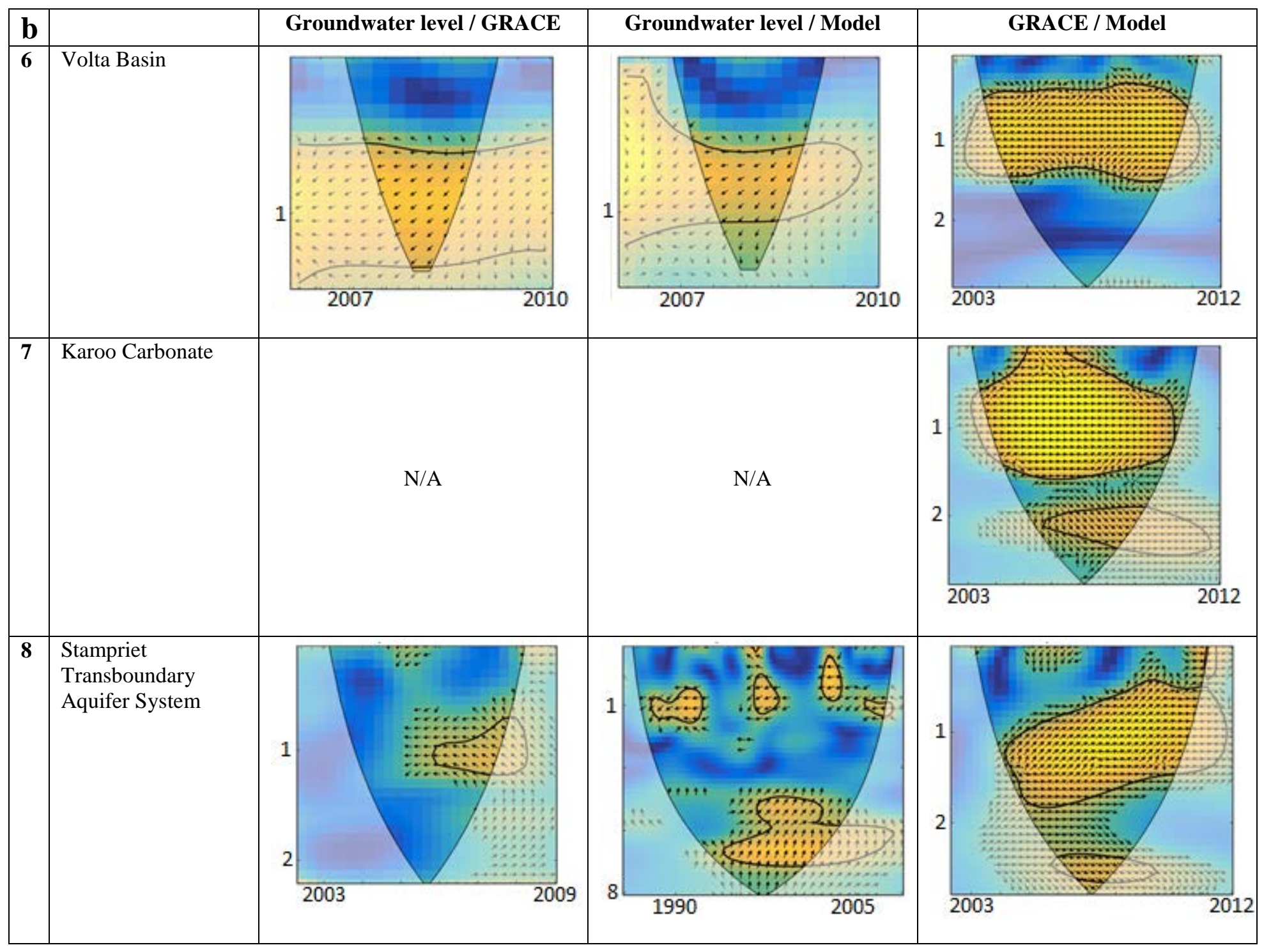




\begin{tabular}{|l|l|l|l|l|l|l|l|}
\hline 9 & Karoo Sedimentary & N/A & & & \\
\hline
\end{tabular}


Figure 5 - Groundwater storage variability and its association with climate teleconnections in Northern Africa (1982-2011): a Northern Atlantic Oscillation (NAO) and Atlantic Multi-Decadal Oscillation (AMO) indices, $\mathbf{b}$ simulated changes in total water storage ( $\triangle \mathrm{TWS}_{\mathrm{MODEL}}$ ), and $\mathbf{c}$

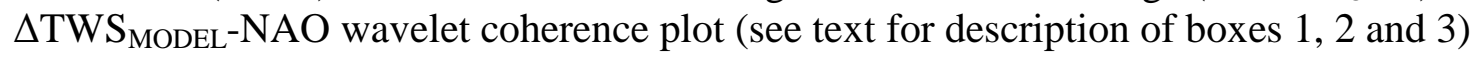
(Note: $\mathrm{x}$-axis is date (year) and $\mathrm{y}$-axis in $\mathbf{c}$ is period in years)
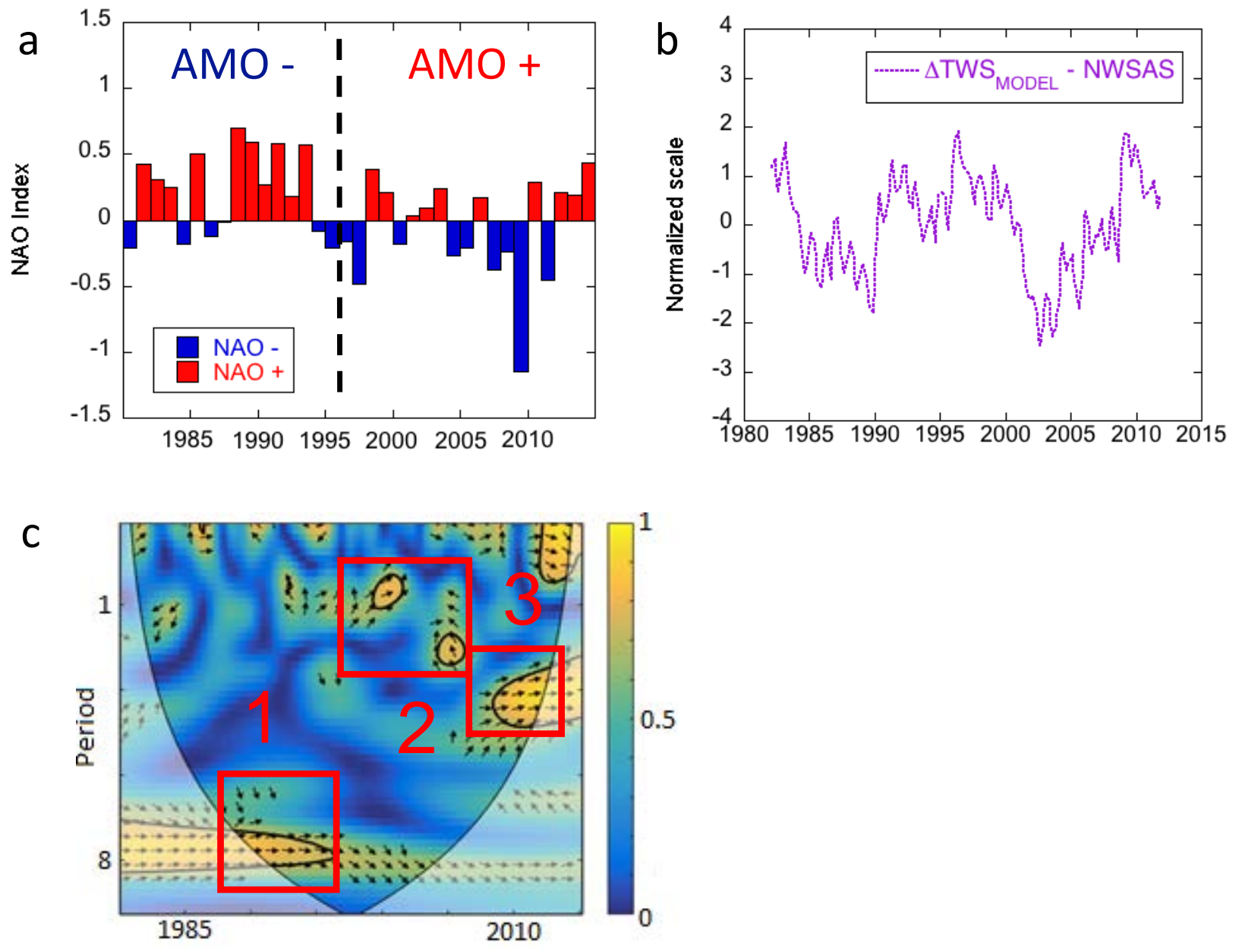
Figure 6 - Groundwater storage variability and its association with climate teleconnections in the Sahel (1982-2011): a Atlantic Multi-Decadal Oscillation (AMO) index and b simulated changes in total water storage $\left(\triangle \mathrm{TWS} \mathrm{S}_{\mathrm{MODEL}}\right)$
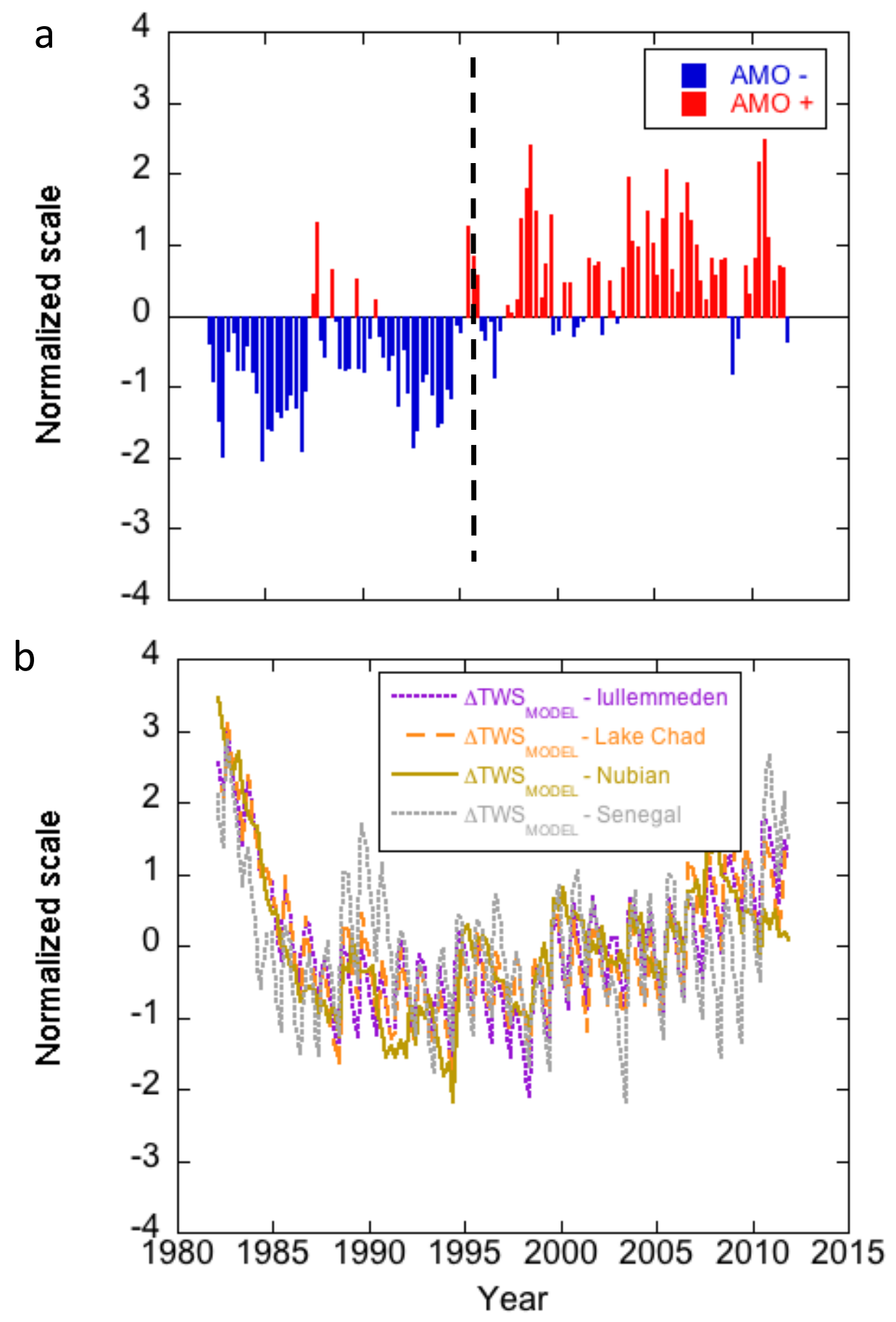
Figure 7 - Groundwater storage variability and its association with climate teleconnections in Equatorial Africa (1982-2011): a Atlantic Multi-Decadal Oscillation (AMO) index and b simulated changes in total water storage $\left(\triangle \mathrm{TWS} \mathrm{S}_{\mathrm{MODEL}}\right)$
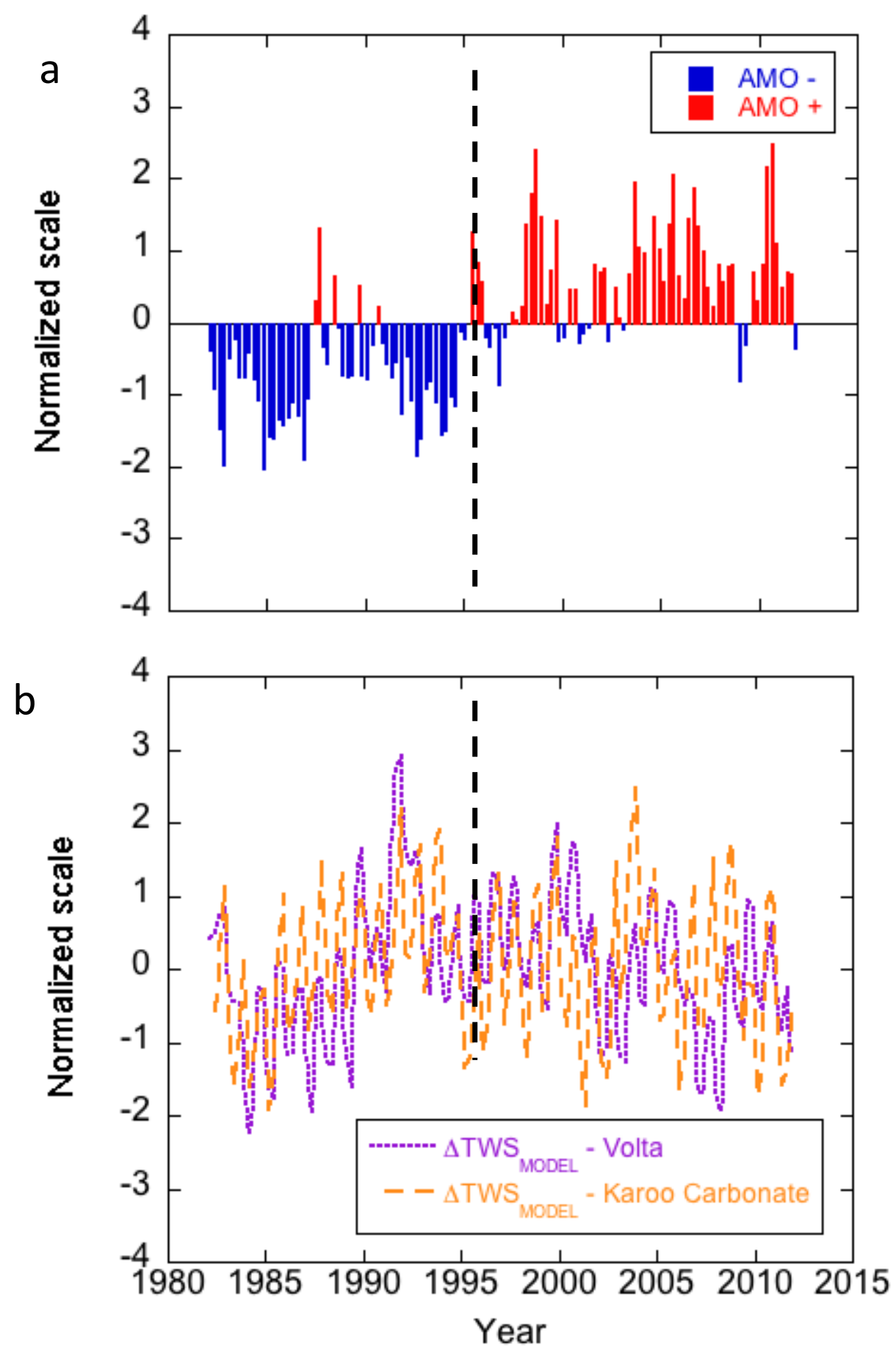
Figure 8 - Groundwater storage variability and its association with climate teleconnections in Southern Africa (1982-2011): a El Niño Southern Oscillation (ENSO) index, b simulated changes in total water storage ( $\triangle \mathrm{TWS}_{\mathrm{MODEL}}$ ); and $\Delta \mathrm{TWS}_{\mathrm{MODEL}}$-ENSO wavelet coherence plots for the $\mathbf{c}$ Karoo Sedimentary Aquifer and $\mathbf{d}$ Stampriet Transboundary Aquifer System (Note: $\mathrm{x}$-axis is date (year) and $\mathrm{y}$-axis in $\mathbf{c}$ and $\mathbf{d}$ is period in years)
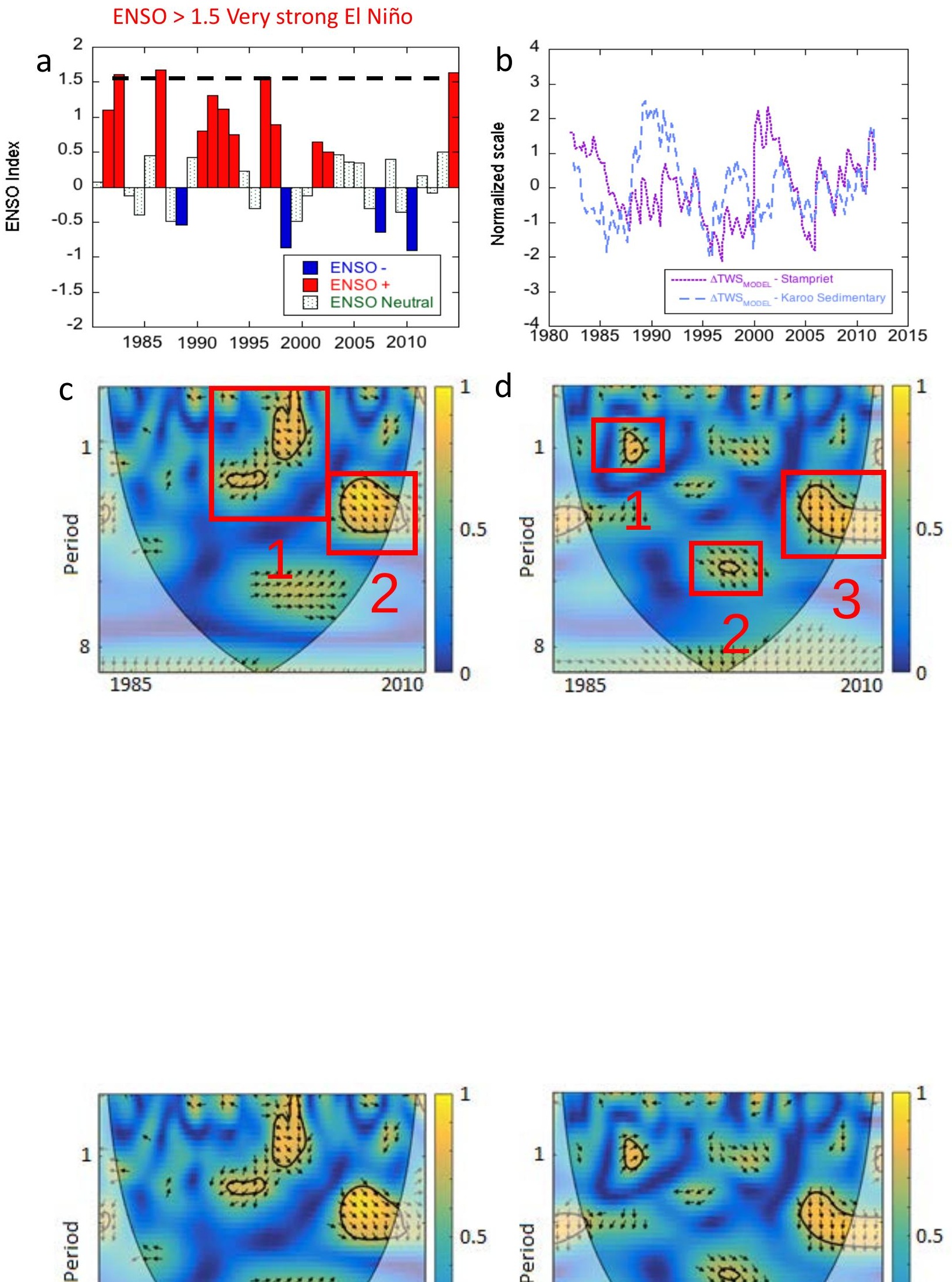
Figure 9 - Groundwater storage variability and its association with climate teleconnections in the Sahel (1982-2011): a El Niño Southern Oscillation (ENSO) index, b simulated changes in total water storage $\left(\Delta T \mathrm{TWS}_{\mathrm{MODEL}}\right)$; and $\triangle \mathrm{TWS} \mathrm{SODEL}_{\mathrm{MNO}}-\mathrm{EN}$ wavelet coherence plots for the $\mathbf{c}$ Nubian Sandstone Aquifer System and d Senegalo-Mauritanian Basin Aquifer (Note: $\mathbf{x}$-axis is date (year) and $\mathbf{y}$-axis in $\mathbf{c}$ and $\mathbf{d}$ is period in years)
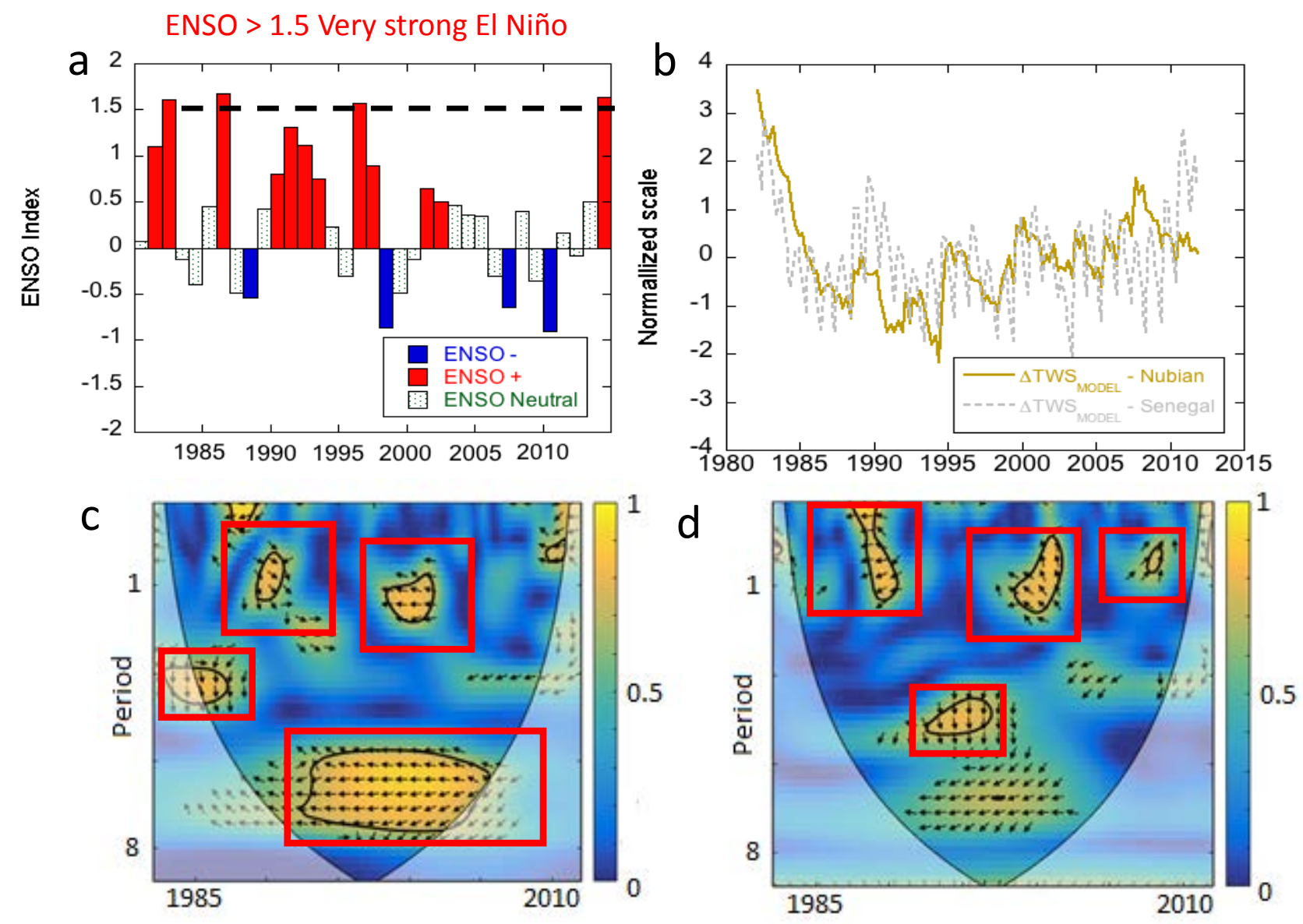
Figure 10 - Groundwater storage variability and its association with climate teleconnections in Equatorial Africa (1982-2011): a El Niño Southern Oscillation (ENSO) index, b simulated changes in total water storage ( $\triangle \mathrm{TWS}_{\mathrm{MODEL}}$ ); and $\Delta \mathrm{TWS}_{\mathrm{MODEL}}$-ENSO wavelet coherence plots for the $\mathbf{c}$ Volta Basin Aquifer and $\mathbf{d}$ Karoo Carbonate Aquifer (Note: $\mathbf{x}$-axis is date (year) and $\mathrm{y}$-axis in $\mathbf{c}$ and $\mathbf{d}$ is period in years)
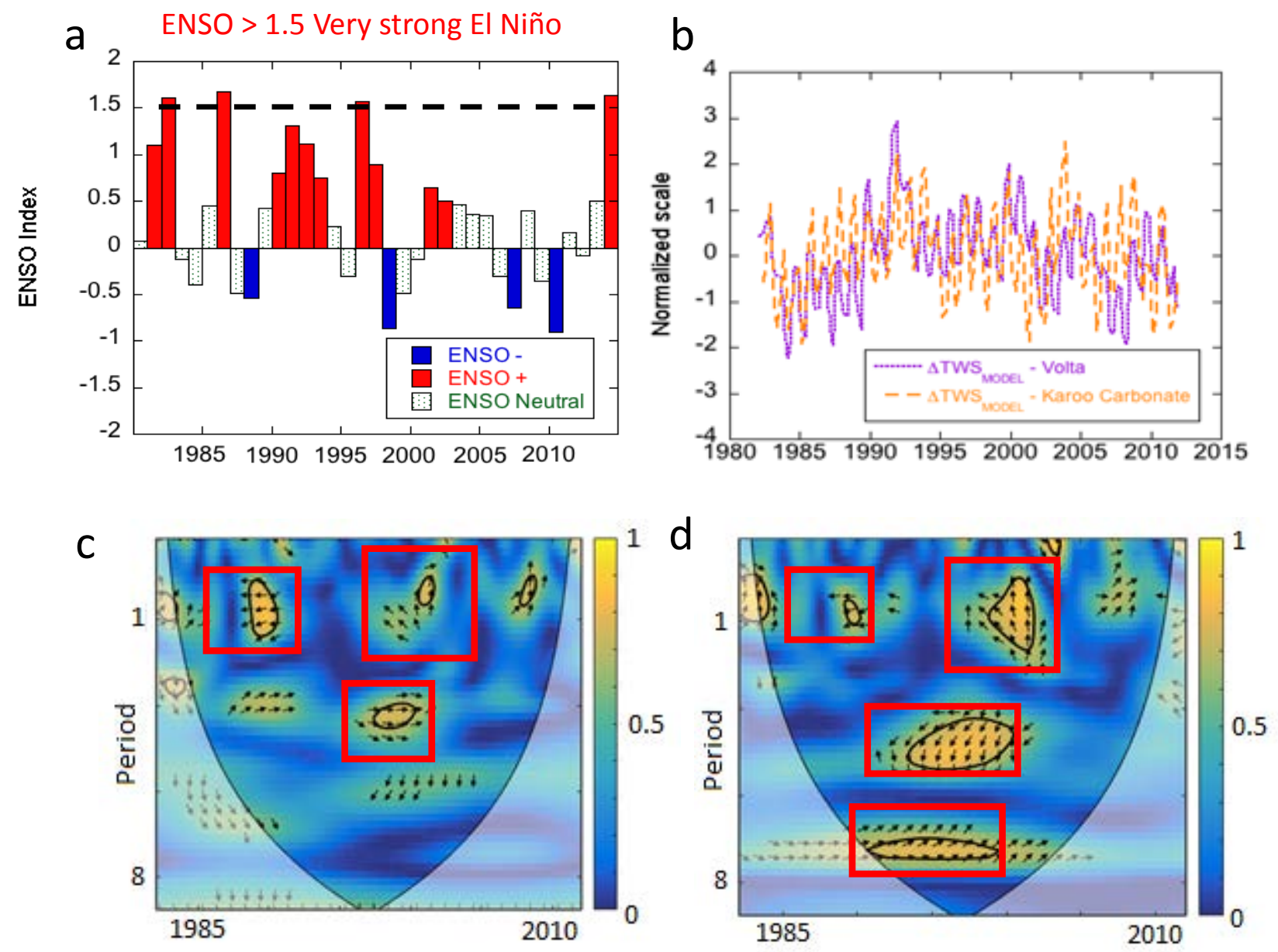
Figure 11 - Groundwater storage variability and its association with the Indian Ocean Dipole (IOD) index in Eastern Africa (1982-2011): a Indian Ocean Dipole (IOD) index, b simulated changes in total water storage $\left(\Delta \mathrm{TWS}_{\mathrm{MODEL}}\right)$; and $\Delta \mathrm{TWS}_{\mathrm{MODEL}}-\mathrm{IOD}$ wavelet coherence plots for the c Nubian Sandstone Aquifer System, $\mathbf{d}$ Karoo Carbonate Aquifer and e Karoo Sedimentary Aquifer

(Note: $\mathbf{x}$-axis is date (year) and $\mathrm{y}$-axis in $\mathbf{c}, \mathbf{d}$ and $\mathbf{e}$ is period in years)
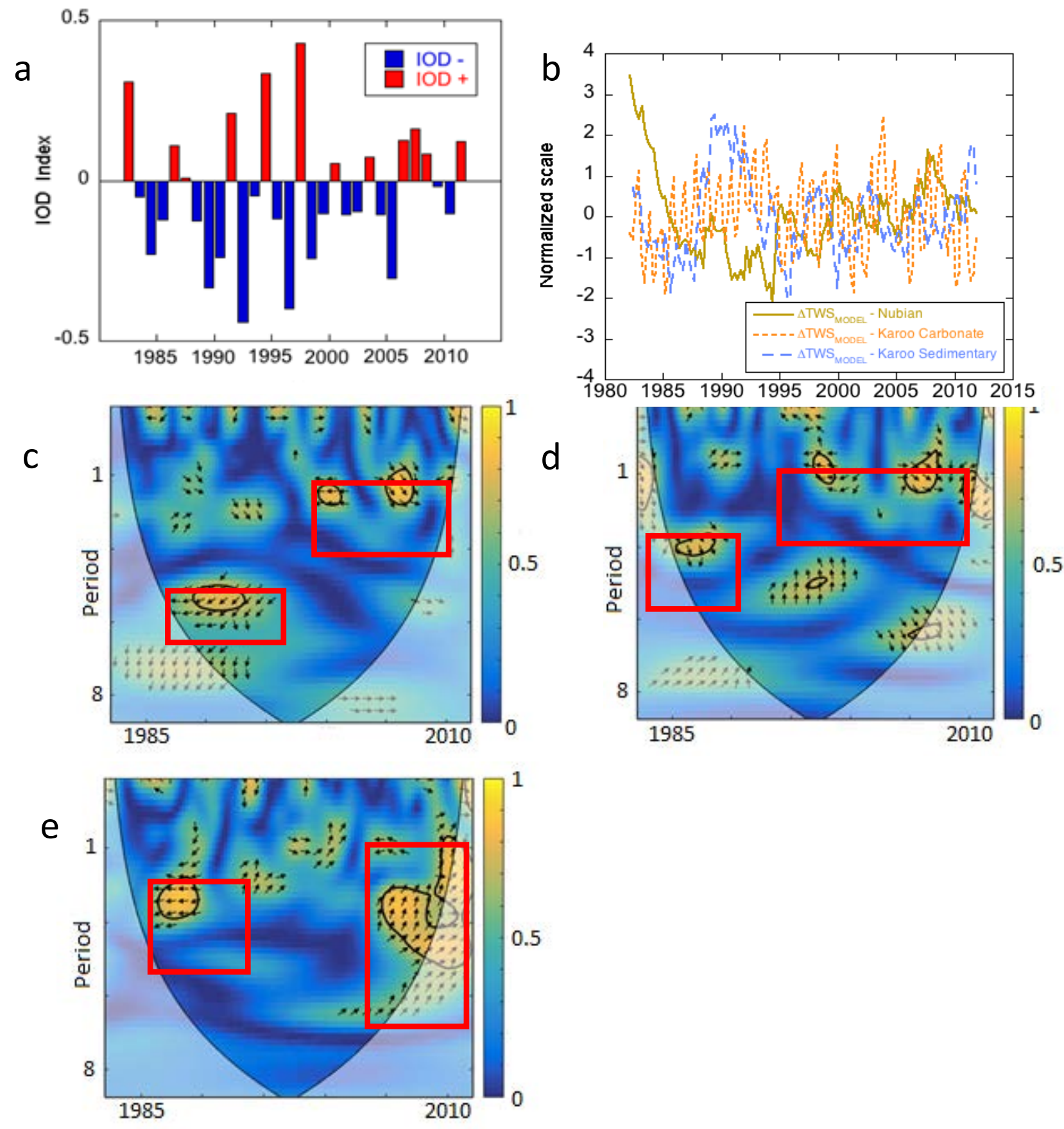